REVIEW OF HISTORICAL SCIENCES 2018, VOL. XVII, NO. 3

http://dx.doi.org/10.18778/1644-857X.17.03.02

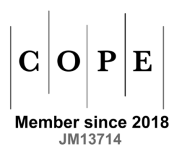

ZBIGNIEW ANUSIK

UNIVERSITY OF LODZ*

\title{
The royal blood. Polish descendants of Sigismund I the Old and Katarzyna Telniczanka in the old Polish times
}

\begin{abstract}
Summary. The research undertaken by the Author concentrates on Polish descendants of Regina, the elder of two daughters of King Sigismund I the Old and his long time mistress - Katarzyna Telniczanka. Until now, it was assumed that the last descendants of the king were his great-grandsons - Władysław Strasz of Białaczów and his sister Krystyna who lived in the first half of the $17^{\text {th }}$ century. Thanks to the documents found by the Author, it was possible to establish that the mother of the above-mentioned Władysław and Krystyna - Urszula Strasz née Kreza, had a sister - Zofia, who married Baltazar Lutomirski. From her daughter, Zofia née Lutomirska $1^{\text {st }}$ married Stanisław Trembiński (Trębiński), $2^{\text {nd }}$ married Franciszek Szamowski, come all descendants of Sigismund I the Old and Katarzyna Telniczanka, both historical and living ones. The article presents a list of all the king's descendants from the beginning of the $16^{\text {th }}$ to the turn of the $18^{\text {th }}$ and $19^{\text {th }}$ century. In total, it was a number of 114 people (58 men and 56 women). It is worth noting that until the end of the first quarter of the $17^{\text {th }}$ century, the descendants of Sigismund I and Katarzyna Telniczanka were Calvinists. They were almost exclusively representatives of wealthy and middle-class nobles. There were no senators among them and only a few were land officers. Yet, the Author's list of the descendants of the penultimate Jagiellon on the Polish throne is by no means complete. In a few cases it was impossible to find source materials that would confirm whether a married couple mentioned in the article had children. Many times the Author had to underline that the fate of a certain person is unknown to him. This stands a chance for further researchers to fill that gap.
\end{abstract}

Keywords: Sigismund I the Old, Katarzyna Telniczanka, genealogy, descendants of Sigismund I the Old's illegitimate daughters in the $16^{\text {th }}-18^{\text {th }}$ century.

* Faculty of Philosophy and History, Institute of History, Department of Modern History / Wydział Filozoficzno-Historyczny, Instytut Historii, Katedra Historii Nowożytnej, e-mail: zanusik@uni.lodz.pl. 
ince the systemic transformation of 1989, there has been a huge increase in interest in the genealogical research in Poland. Attempts are made to develop the genealogical tree of Wenceslaus II, the duke of Racibórz, representative of the side line of the Przemyślids of Bohemia, and, therefore, to create a full database of families that have representatives of ruling dynasties among their ancestors ${ }^{1}$. However, there is no genealogical publication on the descendants of the illegitimate daughters of King Sigismund I the Old who ruled Poland in the years 1506-1548. Thus, in the article in question I will try to fill this research gap.

Let's start with the already known facts. Sigismund, the fifth son of Casimir IV Jagiellon and Elizabeth of Austria, was born on January 1, 1467, in Kozienice. On November 27, 1499, his eldest brother, Vladislaus II, King of Bohemia and Hungary, gave him the Duchy of Głogów as a fief, and in 1501, the Duchy of Opawa (Troppau) as well. In 1504, he was appointed the governor of Lusatia. All those possessions were in Sigismund's hands until the death of his brother, Alexander. On October 20, 1506, he was elected Grand Duke of Lithuania and on December 8 of the same year, during the session of the Piotrków general Diet - King of Poland. He was crowned in Cracow on January 24, 1507. He died in that city on April 1, $1548^{2}$. Probably at the beginning of 1498, Sigismund began his relationship with a woman who for many years was his life companion, that is Katarzyna Ochstat, called Telniczanka. She was born around 1480, perhaps in the village of Telnice, near Brno in Moravia. Her parents are unknown but it is assumed that she came from the bourgeoisie (she had a sister, Małgorzata, married to the Olomouc townsman, Leonard Hohesteiger). From 1498, she was constantly accompanying Sigismund. After his coronation, she settled in Cracow. Her relationship with the king lasted until 1509. At the end of that year, Sigismund decided, taking into account his

${ }^{1}$ See especially R.T. Prinke, A. Sikorski, Polscy potomkowie Piastów $i$ innych dynastii panujacych, Poznań 1997; S. Szybkowski, Zwiazki rodzinne Danaborskich z elita urzędnicza Kujaw i ziemi dobrzyńskiej, 'Roczniki Historyczne' 2000, LXIV, pp. 157-168. In the article in question it was clearly stated that Febronia née Danaborska, the wife of Mikołaj Działyński, was the daughter of Włodko of Danabórz and his first wife, Witocha of Pakość and Krotoszyn. Her children cannot, therefore, be descendants of Wenceslaus II, Duke of Racibórz, as it was suggested in the book by R.T. Prinke and A. Sikorski.

${ }^{2}$ See Z. Wdowiszewski, Genealogia Jagiellonów i Domu Wazów w Polsce, Kraków 2005, pp. 115-117; U. Borkowska, Dynastia Jagiellonów w Polsce, Warszawa 2011, pp. 518-522. 
own matrimony plans, to marry his long time mistress with Andrzej Kościelecki (ca. 1455-1515), the grand treasurer of the Crown. The marriage outraged members of the Kościelecki family as well as the senators. The king cared for Katarzyna's material situation, though. Already in 1510, he granted her a yearly salary of 100 ducats taken from the Cracow Jews. Moreover, on November 21, 1515 , that is after the death of Kościelecki who died on September 6 of that year, he gave her for a lifetime the town of Słomniki and the village of Rakowice near Cracow. In 1517, in turn, he confirmed her rights to a house at Grodzka St in Cracow. When in 1519 the natural son of the king and Katarzyna, Jan of the Lithuanian Dukes, became the Bishop of Wilno (Vilnius), his mother left for Wilno (Vilnius) and settled there permanently. As she had a great influence on her son, she tried to manage the diocese. She felt free to participate in balls as well as to deal with quackery and 'spells'. Perhaps because of her activities, the Lithuanians tried to transfer Jan to one of the Crown bishoprics. Eventually, Katarzyna remained with her son in Vilnius where she died between August 25 and September 10, 1528. Her body was transported to Cracow and on December 11 she was buried in the church in Kleparz. Katarzyna and King Sigismund had the above-mentioned son Jan as well as two daughters, Regina and Katarzyna ${ }^{3}$. With Andrzej Kościelecki, in turn, she had an unknown son, who died before his father, and a posthumous daughter, Beata (1515-1576), who in 1538 married Prince Ilia Ostrogski (ca. 1510-1539). They had famous and unhappy daughter, Halszka of Ostróg (1539-1582). In 1564, at the age of 49, Princess Beata Ostrogska née Kościelecka married a much younger voivode of Sieradz, Olbracht Łaski (15361605). They had no children ${ }^{4}$.

Jan (Janusz) was the eldest child of Sigismund and Katarzyna. He was born on January 8, 1499, in Cracow. It was certain that

${ }^{3}$ See A. Swieżawski, Kościelecka (z Kościelca) Katarzyna, [in:] Polski słownik biograficzny [hereinafter: PSB], vol. XIV, Wrocław-Warszawa-Kraków 1968-1969, pp. 397-398; Z. Wdowiszewski, op. cit., pp. 182-186; U. Borkowska, op. cit., p. 561.

${ }^{4}$ See A. Swieżawski, Kościelecki (z Kościelca) Andrzej, [in:] PSB, vol. XIV, pp. 398-400; T. Kempa, Dzieje rodu Ostrogskich, Toruń 2003, pp. 53-78; R. Żelewski, Łaska 1. v. Ostrogska z Kościeleckich Beata, [in:] PSB, vol. XVIII, Wrocław-Warszawa-Kraków 1973, pp. 222-224; idem, Łaski Olbracht, [in:] ibidem, pp. 246-250; id em, Ostrogski Ilia (Eliasz), [in:] ibidem, vol. XXIV, Wrocław 1979, pp. 480-481; idem, Górkowa Elżbieta (Halszka z Ostroga), [in:] ibidem, vol. VIII, Wrocław-Warszawa-Kraków 1959-1960, pp. 424-426. 
he would become a priest when he was still a child. Initially, he was called Jan de Thelnicz (Ochstat de Thelnicz). Under that name, in 1510, he was nominated to one of the canonries of the Cracow cathedral. The king asked the Pope to remove any canonical obstacles super defectu natalium the same year. Pope Julius II, under the Roman bull of July 29, 1510, removed all obstacles resulting from Jan's birth as well as legitimised and ennobled him. In 1512, at the king's request, Jan was accepted at provosts in the cathedral chapters of Poznan and Płock. The same year, Sigismund titled his son with a surname of the Lithuanian Dukes (ex ducibus Lithuanie) to underline the fact that he was not a prince of blood but only a natural son of the king. In the years 1512-1516, Jan stayed abroad. At that time, he studied Roman and canon law at the University of Bologna. In 1519, he became a bishop of Wilno (Vilnius) but he still had the right to the income received from the Poznan canonry. Although he took over the diocese, he was not ordained. Over time, Jan of the Lithuanian Dukes became the father's deputy in Lithuania. In 1526, a project of marrying him with the last Mazovian dukes' sister, Anna, and giving him the fiefdom of Mazovia was put forward. Ultimately, however, the project collapsed. Jan was not sure whether he would remain in priesthood. It was not until 1531 that he decided to accept the episcopal consecration. Under the bull of June 28, 1531, Pope Clement VII allowed him to receive the sacrament of holy orders and be consecrated. As Lithuanian noblemen (especially the Gasztołds and Radziwiłłs) were reluctant to Jan, he left Wilno (Vilnius). In 1536, Sigismund I transferred him to the Poznan bishopric. After a formal election by the cathedral chapter (May 5, 1536), Jan renounced the Płock provostry which was taken over by the new bishop of Wilno (Vilnius) - Prince Paweł Holszański. Jan of the Lithuanian Dukes was a great administrator of episcopal estates. He also accumulated considerable personal assets. He officially arrived in Poznań on March 24, 1537. After less than a year spent in the capital of Greater Poland, he fell for a four-day fever, a direct cause of his death. He died on February 18, 1538, in Poznan. He was buried in the Vilnius cathedral. He bequeathed part of his personal assets to his half-sister, Beata Kościelecka. The rest was inherited by Sigismund August. In his will he completely omitted his sister, Katarzyna, and daughters of his second sister 
- Anna, with whom he had been fighting for inheritance after their mother, Katarzyna Kościelecka née Ochstat, who died in $1528^{5}$.

Katarzyna was the third and the youngest child of Sigismund and Katarzyna Telniczanka. She was born around 1503. From early childhood she was living at the Hungarian court of her uncle, Vladislaus II of Hungary. In 1515, she came to Vienna as one of the ladies accompanying Princess Anna Jagiellon during the meeting of Emperor Maximilian I with the rulers of Hungary and Poland. In 1522, the rumour had it that there was the possibility of her marriage with the Moldovan hospodar, Stephen IV. Yet, King Sigismund I definitely opposed the idea and did not allow any talks with the court in Iassi. Probably in 1524, Katarzyna became the wife of the Swabian aristocrat Georg II (III), the count von Montfort. The von Montfort counts, closely associated with the Vienna court, possessed goods in Tyrol, Styria and Carinthia. The husband of the youngest daughter of Sigismund I the Old and Katarzyna Telniczanka was born after 1475 but before 1480 as a son of Count Herman II and Cäcilia von Liechtenstein-Murau. He owned the Pecka, Krems and Monsperg estates as well as the Pfannberg and Tettnang counties. He and Katarzyna had four children: Johann VI, Jakob I, Hermann IV and Christina. He died on May 30, 1544. Katarzyna died before September 9, $1548^{6}$.

The eldest son of Georg and Katarzyna - Johann VI, died at a young age. On February 9, 1553, their second son, Jakob I (15301573), married Kathrin von Fugger zu Kirchberg und Weisenhorn (1532-1585), the daughter of Count Anton and Anna von Rehlinger. The couple had many children: Georg V (born on October 18, 1554), Johann VIII (born on September 20, 1555), Katharina (born on

${ }^{5}$ See A. Swieżawski, Jan (Janusz) z Książąt Litewskich, [in:] PSB, vol. X, Wrocław-Warszawa-Kraków 1962-1964, pp. 439-441; Z. Wdowiszews ki, op. cit., pp. 186-191; U. Borkowska, op. cit., pp. 562-563.

${ }^{6}$ See R. Żelewski, Katarzyna (ok. 1503-1548), żona Jerzego II hr. Montfortu, [in:] $P S B$, vol. XII, Wrocław-Warszawa-Kraków 1966-1967, p. 222; Z. W dowiszewski, op. cit., pp. 194-197; U. Borkowska, op. cit., pp. 564-565; J.N. Vanotti, Geschichte der Grafen von Montfort und von Werdenberg, Belle-Vue, bei Constanz 1845, p. 190; K.H. Burmeister, Graf Georg III. von Montfort-Bregenz-Pfannberg (ca. 1475/80-1544). Eine biographische Skizze, 'Monfort. Vierteljährensschrift für Geschichte, Heimat - und Volkskunde (Gegenwart) Vorarlbergs' 2009, Bd. LXI, pp. 7-27 (here, on p. 19, Franziska, who in 1536 was to marry Gerhard von Manderscheid auf Gerolstein, was mistakenly taken for the daughter of Georg and Katarzyna). 
August 12, 1556), Sibylla (born on December 14, 1558), Sigismund I (born on November 27, 1559), Anton I (born on October 24, 1560), Wolfgang III (born on November 29, 1561) and Jakob II (born on November 18, 1562). Only four of them reached adulthood - Georg, Johann, Katarina and Sibylla. In 1584, the eldest of the siblings - Count Georg V (1554-1590), married a Czech aristocrat, Anna von Lobkowitz (Lobkovic), but he died childless. Johann VIII, the count von Montfort (1555-1619), married in 1587 Sibylla von Fugger with whom he had a son Haug, the consecutive count von Montfort, and a daughter, Katharina. The elder of Count Jakob I's daughters - Katharina (1556-1631), married a Czech magnate, Adam von Neuhaus (Adam II. $z$ Hradce). They had six children of whom only two reached adulthood - son Joachim Ulrich and daughter Lucie Otilie. The younger daughter - Sibylla (1558-1600), married Moriz Christoph von Khevenhüller. After his death, she married in 1597 Johann Baptist von Salamanca, the count zu Orlenberg. She had two children with her first husband - Augustin and Katharina. Hermann IV, the count von Montfort, the youngest son of Georg II (III) and Katarzyna, married Sarah von Schärffenberg. They had only one daughter - Anna Maria (died 1583), who in 1580 married Georg Christoph, the count von Losenstein. Herman IV died before 1564 and his wife in 1566. Herman IV's sister, the only daughter of Count Georg II (III) and Katarzyna, Christina (1525-1610), married in 1544 Christoph von Losenstein auf Schallaburg (died 1558) with whom she had sons Georg and Johann Wilhelm ${ }^{7}$. The list of the descendants of the youngest daughter of Sigismund I the Old and Katarzyna Telniczanka is much longer. Yet, since it is a side thread of our deliberations, I will stop my inquiries on the subject at this point.

Regina was the second child and the elder of two daughters of King Sigismund I the Old and Katarzyna Telniczanka. All Polish descendants of her parents come from her. She was born in 1500 or 1501. On October 18, 1518, she married Hieronim Szafraniec of Pieskowa Skała, Starykon coat of arms. Her dowry of 6000 florins as well as the similar amount of the bride price were secured by her husband's father, Stanisław Szafraniec, on Pieskowa Skała and other landed estates. Regina died in Cracow on May 20, 1526. She

${ }^{7}$ See R. Żelewski, Katarzyna..., p. 222; Z. Wdowiszewski, op. cit., p. 196; U. Borkowska, op. cit., p. 196; J.N. Vanotti, op. cit., p. 190; K.H. Burmeister, op. cit., pp. 18-19; idem, Montfort, von (Grafen von Montfort), [in:] Neue Deutsche Biographie, Bd. XVIII, Berlin 1997, pp. 51-54. 
was buried two days later in one of the churches on the Wawel Hill. She and Szafraniec had three daughters: Katarzyna, Anna and Zuzanna ${ }^{8}$. Regina's husband - Hieronim Szafraniec (ca. 14901554/55) was the son of the Nowy Sacz castellan, Stanisław (died 1525), and his first wife, Zuzanna Buczacka, Awdaniec coat of arms (died 1501). From 1519, he was the starost of Chęciny. From 1537 until at least 1554, he was the royal secretary. He took part in the battle of Obertyn. He was also one of the first supporters of the Reformation in Poland. On August 7, 1527, he wrote the sum of 6000 florins, being the dowry of their mother, to his underage daughters and then secured it, with the consent of the king, on the Wolbrom tenure. After Regina's death, he got married twice. In August 1527, he married Zofia Zborowska, Jastrzębiec coat of arms (died 1544), the daughter of Andrzej, the castellan of Żarnów, and the niece of Chancellor Krzysztof Szydłowiecki. Before May 20, 1549, he married Anna Wasilińska (Wasilewska), the townswoman of Olkusz. From his second marriage he had a daughter, Zofia (died 1566/67), who from 1546 was a wife of Mikołaj Oleśnicki of Pińczów, as well as a son, Mikołaj, who died shortly after his father's death, that is before the beginning of November 1555 . He and his third wife had five children: Piotr, Stanisław, Barbara, Anna and Konstancja9.

The youngest daughter of Hieronim Szafraniec and Regina - Zuzanna, died as a young lady. The eldest - Katarzyna, married Ignacy's son, Andrzej Jasieński, Poraj coat of arms, and after his death she married Remigian Chełmski, Ostoja coat of arms (died ca. 1575), one of the leaders of the Calvinist nobility in Lesser Poland. The date of Katarzyna's death is unknown but she was still alive in 1565 . She died childless or at least had no children who outlived her. It seems that information given by Stanisław Szczotka, the author of Remigian Chelmski's biography in the Polski słownik biograficzny [Polish Biographical Dictionary], that Chełmski had two sons unknown by name whom he educated abroad, concerns his nephews. It is also possible, though, that both

${ }^{8}$ See Z. Wdowiszewski, op. cit., pp. 192-193; U. Borkowska, op. cit., pp. 563-564.

${ }^{9}$ See A. Biedrzycka, Szafraniec Hieronim (Jarosz) z Pieskowej Skały, [in:] $P S B$, vol. XLVI, Warszawa-Kraków 2009-2010, pp. 436-439; Z. Wdowiszewski, op. cit., pp. 193-194; U. Borkowska, op. cit., p. 564 (here incorrect information that Hieronim Szafraniec was married five times; the first two wives attributed to him were, in fact, not his but his father's). 
sons of Remigian Chełmski died before their mother, the fact that forced Katarzyna Szafraniec's husband to withdraw from the fight for the Włoszczowa demesne after her death. The third daughter of Hieronim Szafraniec and Regina - Anna (died ca. 1557), married a royal captain (rotmistrz), Mikołaj Kreza of Bobolice, Przeginia coat of arms ${ }^{10}$.

We know relatively little about the husband of Anna Szafraniec, Mikołaj Kreza of Bobolice. He was the son of Mikołaj Kreza (died 1506), the starost of Lwów and Przemyśl, the first family's owner of Bobolice castle, and his wife Dorota. He must have been born around 1500 since he participated in the battle of Sokal of August 2,1519 . He was taken prisoner by the Tatars and spent two years in captivity. Then, he was sold to Turkey where he spent next five quarters as a slave. From the inscription on his epitaph included in Szymon Starowolski's work comes the information that he promised his Turkish master that if he released him from captivity for the word of honour and let him go home, he would return to him at the agreed time, bringing a fixed amount of ransom. When he kept his word, the Turk, pleased with the fact, not only gave up the money for the ransom, but also gave him a beautiful horse. After his return to the country, Kreza served in the army. He married Szafraniec probably around 1540. In April 1550, in Cracow, he filed a protest against his father-in-law, Hieronim Szafraniec, who had not kept the deadline for transferring the sum of 1200 florins. Mikołaj Kreza, like Szafraniec and the husbands of two of his other daughters (Katarzyna and Zofia), was a Calvinist ${ }^{11}$.

${ }^{10}$ See Z. Wdowiszewski, op. cit., pp. 192-193; A. Biedrzycka, op. cit., p. 438; S. Szczotka, Chełmski Remigian, [in:] PSB, vol. III, Kraków 1937, p. 286; W. Urban, Umiejętność pisania $w$ Małopolsce $w$ drugiej połowie XVI wieku, 'Przegląd Historyczny' 1977, vol. LXVIII, issue 2, p. 234 (here information that Remigian Chełmski was still alive in 1575); K. Niesiecki, Herbarz polski, ed. J.N. Bobrowicz, vol. VIII, Lipsk 1841, pp. 506-507 (here information that Hieronim Szafraniec and his wife née Kościelecka [that is Regina in question] had three daughters - Zuzanna, who died in maidenhood, Katarzyna, $1^{\text {st }}$ married Andrzej Jasieński, $2^{\text {nd }}$ married Remigian Chełmski, who died childless and Anna, Mikołaj Kreza's wife).

${ }^{11}$ See D. Quirini-Popławska, Kreza Mikołaj, [in:] PSB, vol. XV, WrocławWarszawa-Kraków 1970, p. 295; A. Boniecki, Herbarz polski, vol. XII, Warszawa 1908, p. 278; Z. Wdowiszewski, op. cit., p. 193; S. Starowolski, Monumenta Sarmatarum, Cracoviae 1655, sheet 781; B. Paprocki, Herby rycerstwa polskiego, ed. K.J. Turowski, Kraków 1858, pp. 368-369; K. Niesiecki, op. cit., vol. V, Lipsk 1840, pp. 382-383; Archiwum Główne Akt Dawnych w Warszawie / The Central Archives of Historical Records in Warsaw [hereinafter: AGAD], Metryka 
After the death of the starost of Chęciny, Kreza - together with his brothers-in-law - Remigian Chełmski and Mikołaj Oleśnicki - tried to take over all of the starost's possessions. They wanted to control Pieskowa Skała with adjacent areas in the Cracow county, Włoszczowa demesne in the Chęciny county and Wolbrom tenure in the Ksiazz county that was pledged 'in old sums' for the amount of 6432 florins. Already in 1555, all three, supported by Stanisław Szafraniec, paternal first cousin once removed of the deceased, tried to annul Hieronim's third marriage and illegitimate his children. At the same time, Chełmski, Kreza and Oleśnicki went to court against the governors of juvenile Mikołaj Szafraniec - Stanisław Tęczyński, the voivode of Cracow, Jan Przerembski, the deputy chancellor of the Crown, as well as Mikołaj Secygniowski and Marian Przyłęcki who after the death of their charge (before November 1555) took care of the children of the Checciny starost from his third marriage. Without going into details of this long-lasting dispute, it should be said that after the death of the main guardian, the voivode of Cracow, Stanisław Tęczyński, who died on December 5, 1560, Oleśnicki, Chełmski and Kreza took over the Pieskowa Skała estate together with the castle. In May 1563, the three of them concluded a settlement with Mikołaj Secygniowski regarding the Włoszczowa estate. Both sides cancelled mutual claims and processes regarding the property. It confirmed the Chełmskis, Krezas and Oleśnickis rights to Włoszczowa and all villages belonging to that demesne. At the same time, Hieronim Szafraniec's sons-in-law decided to give the Wolbrom tenure to Secygniowski to depositum sequestre. In 1564, Zofia Oleśnicka née Szafraniec relinquished her rights to a part of Wolbrom in the benefit of the Cracow land judge, Marian Przyłęcki. Later, Katarzyna Chełmska née Szafraniec did the same and the Wolbrom tenure passed into the hands of Przyłęcki. In this situation, in 1565 Secygniowski sued the Chelmskis, Krezas and Oleśnickis and accused them of not meeting the conditions of the settlement concluded in May 1563. Interestingly, in Secygniowski's suit included in the books of Cracow castle Mikołaj Kreza's late wife is consistently called Zuzanna of Pieskowa Skała ${ }^{12}$.

Koronna / The Crown Metrica [hereinafter: MK] 78, sheets 21v-22; J. Pielas, Oleśniccy herbu Dębno w XVI-XVII wieku. Studium z dziejów zamożnej szlachty doby nowożytnej, Kielce 2007, p. 219.

${ }^{12}$ See K. Chłapowski, Realizacja reform egzekucji dóbr 1563-1665. Sprawa zastawów królewszczyzn małopolskich, Warszawa 1984, pp. 67, 215; A. Biedrzycka, 
Anna Kreza née Szafraniec died at the beginning of 1557. Since then, her children became parts in trials for Hieronim Szafraniec's inheritance as heirs of their mother and grandfather. Thus, we know that the couple had three sons: Jan, Marcin and Jakub as well as four daughters: Dorota, Katarzyna, Anna and Regina. There is information on the epitaph of Mikołaj Kreza that he died at the age of 67. This means that he died around 1567. It is probable that the Krezas sold to Stanisław Szafraniec their third part of the Pieskowa Skała estate together with the castle when Mikołaj Kreza was still alive ${ }^{13}$. On March 16, 1574, in Cracow, the sons of Mikolaj and Anna Kreza divided their parents' landed estates. The eldest brother - Jan, inherited the paternity, that is Bobolice castle with the manor, the villages of Niegow with the manor and right to submit the candidate for a post of the local rector, Mzurów with the manor, Tomiszewice, Lgota, Ogorzelik, Zdów as well as empty villages of Bobolki, Niegówka, Sadowie and pledged villages of Dąbrówno and Zalesice. The younger brother - Marcin, received the maternity, that is estates once belonging to the Krezas' grandfather, Hieronim Szafraniec. His inheritance included: the town of Włoszczowa with the voytship, the village of Włoszczowa with the manor and right to submit the candidate for a post of the local rector as well as the villages of Wola Wiśniowa, Nieznanowice with the manor, Zabrzec, Sułków, Ostrów, Borowe Karczmy, Czartoszowy, Jedle, Łopuszno and Mniów. While taking over those goods, the younger of the Kreza brothers became responsible of securing material interests of the remaining siblings - brother Jakub as well as sisters Katarzyna and Anna. The latter, the wife of Florian Ciekliński, had a dowry secured on the Bobolice estate. Thus, brothers agreed that Marcin

op. cit., p. 438 (here information that the widow of Hieronim Szafraniec proved the legality of her marriage whereas her sons, under an agreement of 1570 , received the villages of Ludynia, Kozłów and Częstków of the Włoszczowa demesne); J. Pielas, op. cit., pp. 196-199; J. Kurtyka, Latyfundium tęczyńskie. Dobra i właściciele (XIV-XVII wiek), Kraków 1999, p. 197; Archiwum Narodowe w Krakowie / The National Archives of Krakow [hereinafter: ANK], Castriensia Cracoviensia Inscriptiones [hereinafter: CCI] No. 89, pp. 1325-1330.

${ }^{13}$ See J. Pielas, op. cit., p. 197; ANK, CCI No. 89, pp. 1325-1330; No. 91, pp. 1126-1127; B. Paprocki, op. cit., p. 369 (here information that Mikołaj Kreza and Anna née Szafraniec had three sons, Jan, Marcin and Jakub, as well as four daughters); S. Starowolski, op. cit., p. 781; I. Kaniewska, Szafraniec Stanisław $z$ Pieskowej Skały, [in:] PSB, vol. XLVI, p. 477 (here information that before 1567 Remigian and Katarzyna Chełmska sold to Szafraniec a third part of the Pieskowa Skała estate together with the castle). 
would transfer this claim from Bobolice to the Włoszczowa estate. As to guarantee the conditions of the then performed division of the goods, a fund of 20,000 florins was raised ${ }^{14}$. As in March 1574 Dorota and Regina, the daughters of Mikołaj and Anna Kreza, did not participate in the division of the inherited goods, we may assume that both died childless before that date.

The youngest of the Kreza brothers - Jakub, also died a few weeks later. Already on April 8, 1574, Marcin Kreza released Jan from payment of 500 florins, that is half of the sum that the latter had previously written to his brother Jakub ${ }^{15}$. We know nothing about the fate of the elder daughter of Mikołaj and Anna Kreza - Katarzyna. She probably died unmarried and childless. A little more can be said about their younger daughter, Anna. As I mentioned earlier, when goods after her parents were being divided, she was married to Florian Ciekliński, Awdaniec coat of arms. It is confirmed by other source materials, too. On February 26, 1574, King Henry of France (de Valois) agreed that Florian Ciekliński and his wife Anna, the daughter of the late Mikołaj Kreza of Bobolice, would purchase the Częstochowa voytship and take it as a lifelong possession ${ }^{16}$. We also know that the Cieklińskis were the users of the royal villages of Placskowice and Turowice in the Opoczno county. On April 6, 1590, King Sigismund III Vasa allowed Florian Ciekliński and his wife Anna to rent those villages to any person, and on June 15, 1593, he agreed that Anna of Bobolice, the widow of Florian Ciekliński, could cede villages of Plasskowice and Turowice to her son, Jan ${ }^{17}$. The latter one was a border bailiff of Sandomierz (in 1608), Opoczno (in 1609-1612) and Checciny (in 1612). Twice, in 1622 and in the years 1627-1628, he was a sub-prefect and judge in the starost court of Nowe Miasto Korczyn. He died at the end of 1632 or at the beginning of 1633. On February 15 of that year, Władysław IV Vasa granted the royal villages of Plaskkowice, Turowice and Rudzisko to his courtier, Aleksander Brzeski ${ }^{18}$.

${ }^{14}$ See AGAD, MK 111, sheets 180-182. It should be added here that last name of Florian Ciekliński, Kreza's brother-in-law, was misspelled in the register in question and written down as Florian Kietliński.

${ }^{15}$ See AGAD, MK 111, sheets $129 \mathrm{v}-130$.

${ }^{16}$ See AGAD, MK 112, sheets $54 \mathrm{v}-55 \mathrm{v}$.

${ }_{17}$ See AGAD, MK 133, sheets 437v, 570-571.

${ }^{18}$ See J. Pielas, Urzędnicy grodzcy nowokorczyńscy i ich kariery $w$ XVII wieku, [in:] Dzieje biurokracji, vol. IV, part 1-2, eds A. Górak, K. Latawiec, D. Magier, 
Thus, we may conclude that Jan Cieklinski, who died at the turn of 1632 and 1633, was a descendant of Sigismund I the Old and Katarzyna Telniczanka. The same observation could refer to his children and possible siblings. The problem is that we do not have any reliable elaboration of the genealogy of the Cieklinski family, Awdaniec coat of arms. We may, though, rely on three most spectacular examples. According to Kasper Niesiecki, Florian Ciekliński and his wife née Kreza had a daughter, Zofia, who first married Adam Bielinski, the master of the pantry of Zakroczym, and then Rusiecki, the Warsaw treasurer, as well as three sons - the above-mentioned Jan, the judge in the starost court of Nowe Miasto Korczyn and the border bailiff of Sandomierz; Stanisław, the royal captain, and Mikołaj. Jan, married to Sułowska, was the father of only one daughter who was married to Józef Kowalski, the Wielun chamberlain. In Niesiecki's opinion, captain (rotmistrz) Stanisław, married to Katarzyna Śmiotanka, had only one son, Marcin, the judge in the starost court of Kamieniec and Latyczów. Finally, the last of Florian Ciekliński's sons - Mikołaj, was to be, according to Kasper Niesiecki, the father of three sons - Dobiesław, the castellan of Czechów (the only senator in the family of Ciekliński) married to Katarzyna Zofia Kostka, the daughter of Mikołaj Rafał Kostka, the starost of Malbork, and Zofia née Pilecka; Aleksander, who had two daughters - Kalińska and Miączyńska; and Jakub ${ }^{19}$. Seweryn Uruski introduced only few amendments to Niesiecki's armorial. Zofia was not mentioned as a child of Florian Cieklinski there. Jan was not married to Sułowska but to Anna Wielogłowska. His alleged daughter was not mentioned either. Another change made by the authors of the armorial in question was the statement that Kalinska and Miaczyńska were not daughters of Aleksander but of his brother, the castellan of Czechów, Dobiesław ${ }^{20}$. K. Niesiecki's findings contain at least three important errors, though. The aforementioned captain (rotmistrz) Stanisław was not the son of Florian but of his cousin and royal secretary, Piotr Ciekliński ${ }^{21}$. Moreover, no Józef Kowalski held

Lublin-Siedlce 2011, pp. 139, 143, 146, 149; A. Boniecki, op. cit., vol. III, Warszawa 1900, p. 172; AGAD, MK 180, sheet 15v.

${ }^{19}$ See K. Niesiecki, op. cit., vol. III, Lipsk 1839, pp. 112-113.

${ }^{20}$ See S. Uruski, A.A. Kosiński, A. Włodarski, Rodzina. Herbarz szlachty polskiej, vol. II, Warszawa 1905, pp. 304-305.

${ }^{21}$ See A. Michałek, Ciekliński Stanisław, [in:] PSB, vol. IV, Kraków 1938, p. 45. 
the office of the Wielun chamberlain ${ }^{22}$ while Katarzyna Plemięcka, not Zofia Pilecka, was the mother of Katarzyna Zofia Cieklińska née $\mathrm{Kostka}^{23}$. In Adam Boniecki's armorial, in turn, there is not a single word about Florian Ciekliński ${ }^{24}$. All in all, zealous Calvinist Mikołaj Ciekliński, who was still alive in 1627, the father of the Czechów castellan, Dobiesław ${ }^{25}$, and perhaps also of Aleksander and Jakub, could have been the son of Florian and Anna Cieklińska née Kreza. Yet, that supposition require clear source confirmation. The same applies to the daughter and sister of Jan, the sub-prefect of Nowe Miasto Korczyn, and the only representative of the Cieklinski family who may be regarded the undoubted descendant of King Sigismund I.

Marcin, the great-grandson of Sigismund I the Old and Katarzyna Telniczanka, the younger son of Mikołaj and Anna Kreza, was undoubtedly an interesting figure. The date of his birth can be estimated approximately for $1542 / 43^{26}$. As it was mentioned earlier, in March 1574 he took over the Włoszczowa estate. It is not certain, however, whether the villages mentioned in the division act belonged entirely to the Krezas. It is possible that the family had rights to parts of some villages. According to Jacek Pielas, already in April 1574 Mikołaj Oleśnicki, one of three sons of Mikołaj of Pińczów (died 1566) and Zofia née Szafraniec (died 1566/67), was mentioned as the owner of the villages of Nieznanowice, Wola Wiśniowa, Zabrzec and Borowe Karczmy. Yet, the Oleśnickis of Pińczów did not manage to keep those goods. Already in 1580, they sold all four villages to Stanisław Szafraniec of Pieskowa Skała who was consistently buying former family estates of Hieronim Szafraniec ${ }^{27}$. It seems that just after the takeover of Włoszczowa, Marcin Kreza ceded to

${ }^{22}$ See Urzędnicy województw łęczyckiego i sieradzkiego w XVI-XVIII wieku. Spisy, elaboration E. Opaliński, H. Żerek-Kleszcz, ed. A. Gąsiorowski, Kórnik 1993.

${ }^{23}$ See A. Boniecki, op. cit., vol. III, p. 171.

${ }^{24}$ See ibidem, pp. 171-172.

${ }^{25}$ See W. Czapliński, Ciekliński Dobiesław, [in:] PSB, vol. IV, p. 42; K. Estreicher, Bibliografia polska, vol. XIV, Kraków 1896, p. 280 (here mentioned the name of Dobiesław's father to whom the latter addressed in 1627 his explanation why he converted to Catholicism); A. Boniecki, op. cit., vol. III, p. 171 (here information that Dobiesław Ciekliński married Eufrozyna Wołucka after his first wife's, Katarzyna Zofia Kostczanka, death in 1644).

${ }^{26}$ In 1567, Marcin and his elder brother, Jan, testified on behalf of they own and their siblings in the case of Stanisław Szafraniec's taking over of Pieskowa Skała. One may assume, therefore, that Marcin was 24 years old at that time. See ANK, CCI No. 91, pp. 1126-1127.

${ }^{27}$ See J. Pielas, Oleśniccy..., pp. 206-207, 210. 
Oleśnicki parts of the villages mentioned here in exchange for the latter's relinquishment of the remaining part of the Włoszczowa demesne. Marcin Kreza was still a wealthy man, even though he ceded the villages from the Nieznanowice estate. He was still the owner of the town of Włoszczowa and the villages of Włoszczowa, Sułków, Ostrów, Czartoszowy, Jedle, Łopuszno and Mniów ${ }^{28}$.

Marcin Kreza was a zealous Calvinist. He actively participated in all events related to Polish dissidents' activities. In 1580, he turned the Catholic church in Włoszczowa into a Calvinist church. He publicly trampled Holly Mass and threw it to dogs the same year. Stephen Bathory admonished and warned him that if a similar offense was repeated, he would be forced to take more decisive action. At the beginning of the eighties of the $16^{\text {th }}$ century, Marcin Kreza brought to Włoszczowa Grzegorz of Żarnowiec (ca. 1528-1601) who became the minister of the Włoszczowa congregation and remained in the town until the end of his days. In 1587, Kreza took part in the congress of the nobility of Lesser Poland near Pokrzywnica and signed its resolutions. In August 1595, Marcin Kreza and Grzegorz took part in the Torun synod. Marcin signed the synod's resolutions. In February 1596, Kreza was the host of the district synod in Włoszczowa. In May 1599, he participated with Grzegorz of Żarnowiec in an evangelical and Orthodox congress in Vilnius. There, he was elected one of the administrators whose aim was to look after co-religionists from Lesser Poland as well as to maintain religious peace. In May 1606, he signed in Cracow a protest against plans of convening the sejmik of the Cracow gentry in Proszowice on June 3 of that year ${ }^{29}$. Like many of his fellow believers, he took part in the Sandomierz rebellion. On June 24, 1607, he signed the

${ }^{28}$ One may suppose that later on Marcin Kreza lost part of the Włoszczowa estate for the benefit of Stanisław Szafraniec who was consistently purchasing estates formerly belonging to Kreza's grandfather - Hieronim, the starost of Chęciny. It is not true, however, that already before $1570 \mathrm{~S}$. Szafraniec 'took over most of the Włoszczowa demesne'. See I. Kaniewska, op. cit., p. 477.

${ }^{29}$ See J. Łukaszewicz, O kościołach braci czeskich $w$ dawnej Wielkopolsce, Poznań 1835, p. 169; idem, Dzieje kościołów wyznania helweckiego w Litwie, vol. I, Poznań 1842, p. 132; J. Wijaczka, Reformacja $w$ miastach prywatnych w Koronie w XVI wieku, 'Roczniki Dziejów Społecznych i Gospodarczych' 2016, vol. LXXVII, p. 389; J. Tazbir, Bluźniercy, którzy uszli karze, 'Nauka' 2011, No. 1, p. 8; H. Kowalska, Grzegorz z Żarnowca, [in:] PSB, vol. IX, Wrocław-WarszawaKraków 1960-1961, pp. 91-93; Volumina legum, ed. J. Ohryzko, vol. II, Petersburg 1859, p. 237; Akta sejmikowe województwa krakowskiego [hereinafter: ASK], vol. I (1572-1620), ed. S. Kutrzeba, Kraków 1932, p. 298. 
dethronement of Sigismund III act issued in the camp at Jezierna. On November 1, 1608, he made a commitment in the books of Cracow castle to repay 600 florins of debt to Andrzej Oleśnicki and 100 florins to Piotr Gruszczyński ${ }^{30}$. It is the last source information about Maciej Kreza that I am aware of. It is probable that he died shortly after.

Marcin Kreza had with an unknown wife (or wives) two sons - Marcin Jr and Piotr. The elder, Marcin, was born in the early eighties of the $16^{\text {th }}$ century. At the turn of 1594 and 1595, accompanied by the Lublin voivode's son, Jan Amor Tarło, as well as Marian Przyłęcki and Jan Gosławski, he began studies in Heidelberg. On January 2, 1595, he signed into the books of the local university as 'iniuratus propter aetatem' which means that he was not over 14 years old at the time ${ }^{31}$. Certainly, he is mentioned in a fragment of the instruction for deputies elected during the sejmik in Proszowice of February 5, 1613. One of the postulates included the statement that 'the case of the Krezas regarding the homicide of the late Marcin, their brother, with Kłobukowski, should absolutely be judged by that Diet ${ }^{32}$. Therefore, the elder of Marcin Kreza sons died before 1613, probably unmarried. His younger brother - Piotr, was probably born in the second half of the nineties of the $16^{\text {th }}$ century. Adam Boniecki noted his presence at the tribunal session in Lublin in $1619^{33}$. On September 28, 1621, Piotr Kreza participated, with his paternal first cousin Aleksander, in a parade of the levy in mass of the Chęciny county

${ }^{30}$ See H. Schmitt, Kilka uwag $w$ sprawie rokoszu Zebrzydowskiego, 'Roczniki Towarzystwa Przyjaciół Nauk Poznańskiego', vol. III, Poznań 1865, p. 62; ANK, CCI No. 187 , pp. 1473-1477.

${ }^{31}$ See D. Żołądź, Studencipolscy z Korony iLitwy na uniwersytecie w Heidelbergu $w$ okresie reformacji, 'Rozprawy z Dziejów Oświaty' 1994, vol. XXXVI, p. 13; and Die Metrikel der Universität Heidelberg von 1386 bis 1662, hrsg. von G. Toepke, Bd. II, Heidelberg 1886, p. 177.

${ }^{32}$ See ASK, vol. I, p. 347. It should be noted here that because it is impossible to clearly distinguish Marcin and Marcin Jr Kreza, it is probable that it was the younger of them who actively participated in the Cracow voivodship's political life of the first decade of the $17^{\text {th }}$ century. It is also uncertain whether information taken from Walerian Nekanda Trepka's work that someone named Kreza rented the voytship in Bochnia from Stanisław Morski and his wife Anna née Cikowska should be attributed to Marcin, Marcin Jr or rather Jan Kreza's son, Aleksander. See W. Nekanda Trepka, Liber generationis plebeanorum 'Liber chamorum', eds W. Dworzaczek, J. Bartyś, Z. Kuchowicz, part 1 (Wstępy wydawców i tekst), Wrocław-Warszawa-Kraków 1963, p. 73.

${ }^{33}$ See A. Boniecki, op. cit., vol. XII, p. 278. 
that took place near Szydłów ${ }^{34}$. He died unmarried and childless probably before April 15, 1624, as there is no information on his participation in the presentation of the Checciny gentry which took place at that time ${ }^{35}$. He was no longer alive on June 25, 1625, when he was clearly mentioned as the deceased ${ }^{36}$.

Jan Kreza of Bobolice, the eldest son of Mikołaj and Anna née Szafraniec, was not very active in the public sphere. After Szymon Starowolski, all armorials mention Mikołaj as a husband of an unknown princess from the Sanguszko family with whom he had son Aleksander. We can add here that Jan Kreza, born probably in the early forties of the $16^{\text {th }}$ century ${ }^{37}$, was not a good landlord. Leading life beyond his means, he heavily indebted the Bobolice estate. The king's secretary, Rev Stanisław Fogelweder, the archdeacon of Warsaw as well as the canon of Cracow, Wilno (Vilnius) and Płock $^{38}$, took advantage of this. He bought Kreza's debts from his creditors and began to take over castle in Bobolice and all villages included in that demesne. On August 26 and August 27, 1588, a number of registers were filed in the Crown Metrica in which Kreza's creditors transferred their rights to debts secured on the Bobolice estate to Fogelweder. Among those creditors there were: Walerian Tęgoborski (520 zlotys on the village of Tomiszowice), Jan Kuczkowski (2700 zlotys on the villages of Mzurów and Niegówka), Stanisław Giebułtowski (1300 zlotys on the village of Zdów), Florian Ciekliński, Kreza's brother-in-law (400 zlotys on the village of Ogorzelik) and Mikołaj Silnicki (2200 zlotys on the

${ }^{34}$ See Rejestr popisu pospolitego ruszenia powiatu chęcińskiego 28 września 1621 roku, [in:] Źródła $i$ materiały do dziejów szlachty województwa sandomierskiego w XVI-XVIII wieku, vol. I (Rejestry pospolitego ruszenia szlachty sandomierskiej $z$ XVII wieku), elaboration J. Pielas, Kielce 2009, p. 30. It is literally written here that 'JMP Aleksander Kryza $z$ Piotrem, synowcem swym, koni 3' [Aleksander Kryza and Piotr, his nephew, presented three horses] during the parade. Piotr was taken for Aleksander's nephew probably because of a huge generation gap between them.

${ }^{35}$ See Rejestr okazowania powiatu chęcińskiego w 1624 roku, [in:] ibidem, pp. 39-44.

${ }^{36}$ See Archiwum Państwowe w Łodzi / The State Archive in Lodz [hereinafter: APŁ], Archiwum Leopoldów z Rzepiszewa / The Archives of Leopolds of Rzepiszew [hereinafter: ALzRz] No. 54, sheet 9v.

${ }^{37}$ Already in 1566, Jan Kreza was said to be the owner of Niegowa village. The next year, together with his brother Marcin, he testified on behalf of they own and their siblings in the case of Stanisław Szafraniec's taking over of Pieskowa Skała. See ANK, CCI No. 91, pp. 505-506, 1126-1127.

${ }^{38}$ More information on him may be found in $\mathrm{t}$. Kurdybacha, Fogelweder Stanisław, [in:] PSB, vol. VII, Kraków 1948-1958, pp. 44-46. 
village of Niegowa). On the same occasion, Kreza got rid of three other debts, giving 112 zlotys to Walerian Tęgoborski, 300 zlotys to Jan Kuczkowski and 100 zlotys to Stanisław Giebułtowski. This, however, only slightly improved his situation. Interestingly, in the registers in question the wife of Jan Kreza - Małgorzata Sanguszko (undoubted princess) was mentioned, as she previously had given her consent to charge the Bobolice estate with further debts ${ }^{39}$. On March 26, 1589, Stanisław Tarnowski, the castellan of Sandomierz, also transferred his rights to debts secured on Bobolice castle and other Jan Kreza's estates to Fogelweder ${ }^{40}$. Shortly thereafter, Stanisław Fogelweder took over the entire Bobolice demesne. In an act of April 15 of that year, in which Sigismund III confirmed the nobility of Stanisław and his nephews, Andrzej, Jost and Stanisław, the archdeacon of Warsaw was already mentioned as Stanisław Fogelweder of Bobolice ${ }^{41}$. Thus, at the beginning of 1589, the Krezas lost the castle in Bobolice and never regained it. It is, therefore, worth correcting the commonly functioning and misleading information that the castle in Bobolice remained in the hands of the Krezas until the end of that family in 1625. The further fate of Jan Kreza is rather unknown. In different armorials he was only reported to have son Aleksander and daughter Urszula ${ }^{42}$. He died before $1600^{43}$.

The main source of information about the life of Aleksander Kreza of Bobolice is the inscription on his grave. We may learn from it that his mother was Princess Sanguszko, that is above-mentioned Małgorzata. This information was sometimes questioned because there is no princess of that name in any genealogy of the Sanguszko family. The cited inscription also contains information that Aleksander Kreza began his military service, fighting under

${ }^{39}$ See AGAD, MK 135, sheets 240-251v.

${ }^{40}$ See ibidem, sheets $442 \mathrm{v}-443 \mathrm{v}$.

${ }^{41}$ See AGAD, MK 133, sheets 352v-355. As registered in the Crown Metrica, on July 30, 1593, Stanisław Fogelweder, owner of Bobolice, donated the village of Mzurów to his nephew Jodok and the Bobolice demesne with the castle to his nephew Stanisław. See AGAD, MK 138, sheets 299v-301.

${ }^{42}$ See K. Niesiecki, op. cit., vol. V, p. 383; A. Boniecki, op. cit., vol. XII, pp. 278-279.

${ }^{43}$ As registered in the books of Sieradz castle, in 1600 Aleksander Kreza, the son of deceased Jan, transferred on Mikołaj Maj, the son of deceased Jan, rights to 3000 florins that Andrzej Szafraniec had given to him as registered in the books of Cracow castle. See AGAD, Sieradzkie grodzkie, inskrypcje / The books of Sieradz castle, inscriptions [hereinafter: SGI] 103, sheet 173. 
Stephen Báthory against Moscow ${ }^{44}$. If that was the case, then it should be assumed that around 1580 Kreza had to be at least 1516 years old. He would, therefore, have been born not later than in 1565. Thus, his parents' marriage had to be concluded shortly before that date. This, in turn, forces us to look for Princess Sanguszko born around 1545. Although at first glance it seems to be difficult to find a married couple among the Sanguszko family that could have had a daughter born at that time, further source research will probably help to solve that puzzle. The heirs of Aleksander Kreza put on his epitaph information on his taking part in the battle of Byczyna and repressing the rebellion of Semen Nalewajka. Kreza also served under Jan Zamoyski in the expedition to Moldova in 1595 and fought against Michał Waleczny (Michael the Brave) in 1600. He also fought in Livonia and in the borderlands against the Turks and the Tatars ${ }^{45}$. He spent the last years of his life in Włoszczowa of which, after the death of his paternal first cousin Piotr, he was probably the only heir. In the presentation of the gentry of the Chęciny county in April 1624 his unit was classified as one sent by widows, orphans, sick and old ones ${ }^{46}$. He died on April 19, 1625, as the last male descendant of the Kreza family ${ }^{47}$. Like his father Jan, uncle Marcin and grandfather Mikołaj, he was a zealous Calvinist until the end of his life.

Urszula Kreza was the daughter of Jan and the sister of Aleksander. As it seems, however, she was not the child of Princess Małgorzata Sanguszko. Urszula married Krzysztof Strasz of Białaczów, Odrowąz coat of arms. As we know from the tombstone inscription of the latter, he was born around $1594^{48}$. On this basis, we may conclude that Strasz married Urszula not earlier than in 1618. It does not seem possible that the bride would be more than 25-28 years old. She must have been born at the earliest in the early nineties of the $16^{\text {th }}$ century or even a little later. She was, therefore, at least 25 years younger than Aleksander which makes it reasonable to recognise her as his half-sister. After the death of her elder brother, she

${ }^{44}$ See S. Starowolski, op. cit., pp. 790-791.

${ }^{45}$ See ibidem, p. 791.

${ }^{46}$ See Rejestr okazowania..., p. 43.

${ }^{47}$ See S. Starowolski, op. cit., p. 791.

${ }^{48}$ See K. Niesiecki, op. cit., vol. V, p. 383; A. Boniecki, op. cit., vol. XII, pp. 278-279; S. Starowolski, op. cit., p. 790. 
took over the town of Włoszczowa with its surroundings (at that time, the Włoszczowa demesne was certainly significantly smaller compared to Marcin Kreza's times). Urszula was a zealous Calvinist while her husband, Krzysztof Strasz of Białaczów - a Catholic. He titled himself the royal secretary (for the first time in February 1636). He fought with Moscow and the Turks under Jan Karol Chodkiewicz. He participated in the war with Sweden for the estuary of the Vistula River in the years 1626-1629. Urszula Strasz née Kreza probably died in 1628 as Krzysztof Strasz married Zofia Oleśnicka, Dębno coat of arms, the daughter of Jan and Izabela nee Chycka, the following year. In the thirties of the $17^{\text {th }}$ century, Krzysztof and Zofia Strasz dissolved the congregation in Włoszczowa and gave back the temple to the Catholics. The second wife of Strasz died in 1636. Krzysztof himself died in 1644 at the age of $50^{49}$.

Krzysztof Strasz and Urszula Kreza had two children - son Władysław, the heir of Włoszczowa ${ }^{50}$ and a courtier of Prince Charles Ferdinand Vasa, and daughter Krystyna. The latter was married to Wawrzyniec Załuski, Junosza coat of arms. Krystyna Załuska née Strasz was still alive in June 1655 when she transferred to her brother her rights to the sum of 4000 zlotys which was owed to her by Stanisław Koryciński, the castellan of Biecz ${ }^{51}$. On January 26, 1658, Władysław Strasz of Białaczów confirmed in the books of Cracow castle an agreement with Mikołaj Chrzanowski ${ }^{52}$. Around 1660, he sold Włoszczowa to Jakub Dąmbski of Lubraniec, Godziemba coat of arms, the standard-bearer of Zator and Oświęcim. As it seems, he never married. Nothing is known about the descendants of his sister, Krystyna Załuska, too. Until now it was believed that Władysław and Krystyna Strasz of Białaczów were the last Polish descendants of Sigismund I the Old and Katarzyna Telniczanka. However, it is not true.

${ }^{49}$ See K. Niesiecki, op. cit., vol. VIII, p. 555; S. Starowolski, op. cit., p. 790; J. Pielas, Oleśniccy..., pp. 317-318; J. Wijaczka, op. cit., p. 389; Rejestr okazowania powiatu chęcińskiego w 1636 roku, [in:] Źródła i materiały do dziejów..., vol. I, p. 46.

${ }^{50}$ See K. Niesiecki, op. cit., vol. VIII, p. 555; S. Starowolski, op. cit., p. 790.

${ }^{51}$ Undoubtedly, the act in question exists as information on its content may be found in the Internet. Unfortunately, I was not able to find it in the books of Cracow castle.

${ }^{52}$ See ANK, CCI 278, pp. 396-397 (the agreement was made in Maluszyn on January 19, 1658). 
After a long search, I managed to find a document that sheds new light on the genealogy of the Kreza family ${ }^{53}$. First, however, we should pay attention to the words used in the inscription on Aleksander Kreza's grave, namely fratrem sororibus - brother to sisters $^{54}$. Not fratrem sorori but sororibus. This may mean only one thing - Aleksander Kreza had, besides Urszula Strasz, one more sister. The one who lived longer than him and made sure that such an information was given on the monument. It was Zofia Kreza of Bobolice, the wife of Baltazar (Jan Baltazar, Baltazar Jan) Lutomirski, Jastrzębiec coat of arms. This is confirmed unequivocally by the document registered by Zofia's husband in the books of Piotrków castle on June 28, 1625. On that day, Lutomirski wrote to his wife 31,000 zlotys secured on all his estates. On that occasion he explained what commitments made up for that sum: 4000 florins of Zofia's dowry and bride price, 4000 florins owed to her as a debt in the books of Chęciny castle, 6000 florins of an inheritance after Piotr Kreza and, most importantly, 17,000 florins of natural succession (succesionis naturalis) after Aleksander Kreza of Bobolice ${ }^{55}$. Since Urszula Strasz née Kreza did not inherit all Aleksander's estates, it could only mean one thing - the other person entitled to the inheritance was his and her sister. The amount of 17,000 florins mentioned here was undoubtedly the repayment which the Lutomirskis received from the Strasz family in return for giving up their right to half of the Włoszczowa estate ${ }^{56}$.

Zofia Kreza of Bobolice was undoubtedly the younger daughter of Jan Kreza, the native sister of Urszula and the half-sister of Aleksander. She was born in the mid-nineties of the $16^{\text {th }}$ century or even several years later. As we know, she married Lutomirski

${ }^{53}$ Years ago, I found information in the books of Łęczyca castle that Zofia nee Kreza was Baltazar Lutomirski's wife. Her father's name was not given in any registry known to me, though. It was not also mentioned that she came from the family that pretended to be 'of Bobolice'. Therefore, the problem in question was to be solved with the use of other archival sources.

${ }^{54}$ See S. Starowolski, op. cit., p. 791.

55 See APŁ, ALzRz No. 54, sheets 9-9v.

${ }^{56}$ On January 20, 1626, Baltazar Lutomirski, who resigned from half of the Włoszczowa estate, received from Krzysztof Strasz last instalment of a financial compensation. Lutomirski made a record in the books of Cracow castle, squared accounts with Strasz on a sum of 3500 florins and ceded to him rights to a claim on a sum of 7000 florins. The same day Baltazar Lutomirski loaned 1500 florins to another Strasz - Jan. See ANK, CCI 224, pp. 28-31. 
before 1625. She died in the first half of $1636^{57}$. Zofia's husband - Baltazar Lutomirski, was the third son and the sixth, the youngest, child of Baltazar Lutomirski (died 1587), the starost of Sieradz and Leżajsk, and Beata Elżbieta née Tarnowska, Leliwa coat of arms, the Sandomierz voivode's daughter. Baltazar was probably born around $1575 / 78^{58}$. Together with his elder brothers - Mikołaj and Stanisław, he was the owner of the town of Lutomiersk and a few adjoining villages in the Szadek county of the Sieradz voivodship. Like his parents and brothers, he was a Calvinist. At the end of the twenties of the $17^{\text {th }}$ century, he bought from Anna Sarnowska of Dalików, the wife of Jan Koniecpolski, later voivode of Sieradz, the village of Krępa in the Szadek county. In September 1631 he leased it to Pawel Malski for three years. In the subsequent years, he had a law suit with the Koniecpolskis for breaching the terms of the sale of $\mathrm{Krepa}^{59}$. After the childless death of his eldest brother, Mikołaj, he took over half of his shares in the Lutomiersk estate. In April 1627, together with his brother Stanisław, he pledged Lutomiersk with its surroundings for 18,000 florins to the widow of Mikołaj - Marianna née Gorajska, the then wife of Stanisław Plichta, the Sochaczew county writer ${ }^{60}$. Shortly after repurchasing the Lutomiersk estate from that pledge, on July 8, 1630, the Lutomirski brothers pledged

${ }^{57}$ See AGAD, Łęczyckie grodzkie, inskrypcje / The books of Łęczyca castle, inscriptions [hereinafter: $\mathrm{EGI}$ ] 169, sheets 332v-335.

${ }^{58}$ On February 5, 1588, Beata of Tarnów, the widow of Baltazar Lutomirski, the starost of Sieradz and Leżajsk, squared accounts with Andrzej Opaliński on a sum of 10,000 florins that were secured by her deceased husband on the Leżajsk tenure. She was at that time the guardian of their underage sons - Mikołaj, Stanisław and Baltazar Jan. See AGAD, MK 134, pp. 103-105. Already in 1592, Beata, the eldest daughter of Baltazar Lutomirski and Beata Tarnowska, was a wife of Jan Bojanowski, the crown lectistrator and the starost of Bobrujsk. See AGAD, MK 137, sheets 220v-221. After his death, she married Jan Baliński of Chomięża, the castellan of Bydgoszcz, and after his death, she married in 1605 Adaukt, that is Zbożny Smerzyński, the Inowrocław voivode's son. In 1609, she widowed for the third time. She was already dead in 1612. See Biblioteka Kórnicka PAN / The Kórnik Library of the PAS [hereinafter: BK PAN], Teki Dworzaczka [hereinafter: TD], Monografie / Monographies, Lutomierscy, Lutomirscy h. Jastrzębiec. In 1593, the second daughter of the starost - Zofia, married Jan Myszkowski of Mirów, later tribune of Oświęcim and Zator. At that moment Jan Baltazar was still underage. See ANK, CCI 148, pp. 191-195, 205-208. The third of the Lutomirski sisters - Anna, married Stanisław Stokowski of Romiszewice. See APE, ALzRz No. 54, sheet 5 .

${ }^{59}$ See APŁ, ALzRz No. 30, sheets 2-10.

${ }^{60}$ See APŁ, ALzRz No. 54, sheets 11-12 (the registry legitimised in the books of Szadek castle on April 20, 1627). 
it for 20,000 florins to the castellan of Łęczyca, Adam Walewski. Two years later, the pledge was changed for a lease and Lutomiersk with its surroundings was in the hands of Walewski until May 30, $1633^{61}$. In the summer of 1636, Baltazar Lutomirski sold his half of Lutomiersk with half of the villages of Czołczyn, Zolew and Wrzaca to the voivode of Rawa Mazowiecka, Andrzej Grudziński ${ }^{62}$ who at the same time bought the other half of the Lutomiersk estate from sons of the deceased Stanisław - Adam and Mikołaj ${ }^{63}$. When in July of that year Baltazar Lutomirski accepted in the books of Łęczyca castle a sales contract of Lutomiersk that was made in Poddębice, his wife was mentioned as deceased ${ }^{64}$. Lutomirski himself died in December 1638 or in the first days of January $1639^{65}$.

Baltazar and Zofia Kreza had one son, Joachim, and two daughters, Anna and Zofia. At the time of their father's death, all the children were still underage. Their first cousins - Adam and Mikołaj Lutomirski, resigned from being their guardians in the benefit of Zygmunt Zapolski, the Sieradz master of the pantry ${ }^{66}$. King Władysław IV, however, did not approve that decision and appointed Jerzy Bełdowski as the guardian of the young Lutomirskis. Bełdowski, acting on behalf of the underage children of Baltazar Lutomirski - Joachim, Anna and Zofia, started legal action in the Sieradz starost court against the buyer of the Lutomiersk estate, Andrzej Grudziński, to obtain the sum of 30,000 florins which constituted the dowry and the bride price of their deceased mother, Zofia Kreza, secured on Lutomiersk and the adjacent villages. In 1639, the starost court awarded the sum to the Lutomirskis. Grudziński was to pay them 10,000 florins per person. Joachim was to receive his sum after reaching the age of 18 , and his sisters - after getting married ${ }^{67}$.

${ }^{61}$ See AGAD, SGI, 137, sheets 199-200v, 314v; SGI, 139, sheets 567-569. See also M. Kobierecki, Walewscy herbu Kolumna w XVII-XVIII wieku. Genealogia. Majętności. Działalność publiczna, Łódź 2008, p. 28.

${ }^{62}$ See AGAD, ŁGI, 169, sheets 332v-335.

${ }^{63}$ A resignation from the Lutomiersk estate in the benefit of Grudziński for a sum of 31,000 florins was legitimised by Mikołaj Lutomirski in the books of Sieradz castle on July 28, 1636. See APE, ALzRz No. 13, sheet 54.

${ }^{64}$ See AGAD, ŁGI, 169, sheet 332.

${ }^{65}$ In the books of Sieradz castle of January 1639 Baltazar Lutomirski was mentioned as 'just deceased'. See AGAD, SGI, 149, sheet 190v.

${ }^{66}$ See ibidem.

${ }^{67}$ See AGAD, ŁGI, 175, sheets 446-447. 
The only son of Baltazar and Zofia Lutomirska - Joachim, the heir of Kreppa, died young and unmarried. Already in 1648, he was mentioned as a deceased ${ }^{68}$. We may assume that Anna, the elder of the Lutomirskis' daughters, died as a young lady. Her younger sister - Zofia, born around 1630, already on June 25, 1650, was the wife of Stanisław Trembiński (Trębiński), Rogala coat of arms, the son of Feliks ${ }^{69}$. They had daughters Teresa and Zuzanna who were recorded in the sources in February $1661^{70}$. After the death of her first husband, Zofia Lutomirska married Franciszek Szamowski, Prus I coat of arms, the son of Stanisław and Helena née Pieczkowska (Pięczkowska), Jelita coat of $\operatorname{arms}^{71}$. She made the annuity agreement with him on April 10, 1659 ${ }^{72}$. Franciszek Szamowski actively participated in public life. He took part in the Łęczyca sejmiks and the Diet. At the ordinary Diet of 1672, together with other deputies from Łęczyca, he outraged King Michał, calling his dress 'clownish'. On May 9, 1684, he was appointed to the office of the Łeczyca master of the pantry. After the death of John III, he was sent to the electoral Diet and participated in the election of August II (Frederick Augustus of Saxony) ${ }^{73}$. Zofia Szamowska née Lutomirska died before August 8, $1691^{74}$. Franciszek Szamowski's second wife was Teresa née Stempowska (Stępowska), the widow of Paweł Prażmowski. He outlived that wife, too. Szamowski's second marriage was childless. On November 19, 1700, in Witaliszewice (Witaszewice) the Łęczyca master of the pantry wrote his will that was accepted in the books of Łęczyca castle. He died shortly afterwards. Franciszek Szamowski and Zofia née Lutomirska had three children: Jan, Jakub and Konstancja $^{75}$.

${ }^{68}$ See APŁ, ALzRz No. 30, sheet 11.

${ }^{69}$ See AGAD, Sieradzkie grodzkie, relacyjne / The books of Sieradz castle, accounts $28 \mathrm{a}$, sheet $512 \mathrm{v}$.

${ }^{70}$ See AGAD, ŁGI, 220, sheets 20-24v.

${ }^{71}$ See AGAD, ŁGI, 175, sheets 339-341. Helena Szamowska née Pieczkowska was the daughter of Maciej and Anna née Tarnowska, Rola coat of arms. See also M. Kobierecki, op. cit., p. 93 (here wife of Szamowski was called Helena Piechowska).

${ }^{72}$ See AGAD, ŁGI, 215, sheets 57-57v. Here I would like to thank Hanka Żerek-Kleszcz PhD for her help in processing the genealogy of the Szamowski family as well as for sharing the information on the history of that family.

${ }^{73}$ See L.A. Wierzbicki, Szamowski Franciszek, [in:] PSB, vol. XLVI, pp. 588-589.

${ }^{74}$ In a certificate registered that day in the books of Łęczyca castle she was mentioned as a deceased. See AGAD, tGI, 285, sheets 232-232v.

${ }^{75}$ See AGAD, Łęczyckie grodzkie, relacje / The books of Łęczyca castle, accounts 177, sheets 224-224v; L.A. Wierzbicki, op. cit., p. 588. 
Nothing more is known about Teresa, one of the daughters of Stanisław Trembiński (Trębiński) and Zofia Lutomirska. She probably died as a young lady. The second daughter of the couple, Zuzanna Trembińska (Trębińska), married in February 1670 Ludwik Grodziecki of Wyszyna, Dryja coat of arms, the son of Adam, the castellan of Międzyrzecz. From her mother and stepfather she received a dowry of 36,000 zlotys $^{76}$. Her husband died shortly after the wedding and the couple was childless. Zuzanna married for the second time already in 1671. Her second husband was Adam Lubstowski, Leszczyc coat of arms (died on April 21, 1701), the Inowrocław master of the pantry, the son of Mikolaj, the starost of Kruszwica, and Zofia Kołudzka ${ }^{77}$. At the end of his life he became the castellan of Kowal ${ }^{78}$. Zuzanna Lubstowska née Trembińska (Trębińska) died after 1681 but before 1685 when her husband married Izabela Eufrozyna Mielęcka, the widow of Władysław Latalski of Łabiszyn. Adam and Zuzanna Lubstowska had five children: sons Andrzej and Maciej as well as daughters: Marianna Dorota, Zofia and Izabela. The latter became a Norbertine in Strzelno. She died before $1727^{79}$. The eldest daughter of the castellan of Kowal, Adam Lubowski, and Zuzanna née Trembińska (Trębińska) - Marianna Dorota, married in 1697 Antoni Przecław Rupniowski, Szreniawa coat of arms, who used the title of the cup-bearer of Owrucz ${ }^{80}$. She widowed before 1715 as at that time Antoni Leszczyński was her second husband. Both of them were still alive in $1734^{81}$. She and Rupniowski had son Konstanty Wiktor, as it was recorded in the books of Kalisz castle in $1763^{82}$. Konstanty Wiktor Rupniowski and his wife, Marianna Doruchowska, had son Jan Nepomucen who in 1791 (when his parents were still alive) married Wiktoria Kozłowska, the daughter of Jakub and Józefa

${ }^{76}$ See BK PAN, TD, Grodzkie i ziemskie / Castle and land books [hereinafter: GiZ], Konin, 10018 (No. 60), 1670.

${ }^{77}$ Already before the wedding, he secured 9000 zlotys of the dowry and 9000 zlotys of the bride price on his estates in the benefit of Zuzanna. See ibidem, Konin, 10043, (No. 60), 1671.

${ }^{78}$ See Urzędnicy kujawscy i dobrzyńscy XVI-XVIII wieku. Spisy, elaboration K. Mikulski, W. Stanek, Z. Górski, R. Kabaciński, ed. A. Gąsiorowski, Kórnik 1990, p. 123.

${ }^{79}$ See BK PAN, TD, Monographies, Lubstowscy h. Leszczyc.

${ }^{80}$ See BK PAN, TD, GiZ, Konin, 11668, (No. 70), 1697.

${ }^{81}$ See BK PAN, TD, Monographies, Leszczyńscy różni.

${ }^{82}$ See BK PAN, TD, GiZ, Kalisz, Inscriptions, $17^{\text {th }} / 18^{\text {th }}$ century, 6456 (No. 204/205), 1763. 
Gołecka, the widow of Jakub Myszkowski ${ }^{83}$. Marianna Dorota née Lubstowska and Antoni Leszczyński had son Józef who later married Rozalia Lubiatowska. Józef Leszczyński died childless before $1742^{84}$.

The second daughter of the castellan of Kowal, Adam, and Zuzanna née Trembińska (Trębińska), Zofia Lubstowska, married in 1701 Jan Pawel Szygowski, Trzaska coat of arms, the starost of Kruszwica. She was a widow before 1716 . Shortly after, she became the wife of Jan Antoni Tarchalski. In 1720, in turn, she married Franciszek Maciej Jarnowski, Topór coat of arms, the master of the hunt of Brześć Kujawski. She died before 1741. She did not have children with her second and third husband ${ }^{85}$. With Jan Pawel Szygowski she had sons Adam, Aleksander, Władysław, Konstanty and Stefan as well as daughters Ludwika and Katarzyna. The eldest daughter of Zofia Lubstowska, Ludwika Szygowska, already in 1716 married Stanisław Domaradzki ${ }^{86}$. She died, probably childless, after 1723. Władysław and Stefan Szygowski died probably before 1719 because since then they were not mentioned in the sources in which Aleksander, Konstanty, Ludwika and Katarzyna appeared. After 1716, Adam Szygowski was mentioned only once, in a note from 1736. It may be assumed that if it was not a mistake of a writer of the castle records, Szygowski died unmarried and childless soon after ${ }^{87}$. In 1735, Katarzyna married Antoni Raczyński, Nałęcz coat of arms. They had three sons - Ignacy, a Jesuit, Jan, the Poznan canon, and Wojciech, the captain of the Crown troops. Antoni and Katarzyna Raczyńska died before $1770^{88}$. Konstanty Szygowski, the son of Jan Pawel, the starost of Kruszwica, and Zofia nee Lubstowska, married Zofia Borek Gostyńska, Gryzima coat of arms, the daughter of Adam

${ }^{83}$ See BK PAN, TD, GiZ, Kościan, Inscriptions, 11378 (No. 337), 1791.

${ }^{84}$ See BK PAN, TD, Monographies, Leszczyńscy różni.

${ }^{85}$ See BK PAN, TD, Monographies, Lubstowscy h. Leszczyc; TD, Zap. Tryb. Piotrk. [hereinafter: ZTP], 540 (No. 41), 1723 (here Marcin Tarchalski is mentioned as the heir of brother Jan Antoni); GiZ, Poznań, Inscriptions, $17^{\text {th }} / 18^{\text {th }}$ century, 10551 (No. 121/I), 1727 (here Franciszek Maciej Jarnowski is said to be the adoptive father of the children of his first wife, Krystyna Chełkowska, and her former husband, Stanisław Golemowski).

${ }^{86}$ See BK PAN, TD, GiZ, Nakło, part 1, 6147, (No. 199), 1716 (here all children of Jan Paweł Szygowski and Zofia Lubstowska are mentioned).

${ }^{87}$ See BK PAN, TD, GiZ, Kcynia, 5539 (No. 134), 1719; GiZ, Gniezno, part 1, 12359 (No. 97), 1735; 12477 (No. 97), 1736.

${ }^{88}$ See BK PAN, TD, GiZ, Kościan, Inscriptions, 10683 (No. 331), 1770; GiZ, Poznan, Inscriptions, $17^{\text {th }} / 18^{\text {th }}$ century, 16960 (No. 1356), 1779; 17080 (No. 1357), 1780. 
and Dorota Radzyńska of Werbno. He died childless before $1770^{89}$. Last of the Kruszwica starost's son, Aleksander Szygowski, married Katarzyna née Stolińska. They had three children: Józef, Augustyn and Marianna, the wife of Kazimierz Ostrowski from 1766. There is nothing more known about Józef and Marianna. Around 1779 Augustyn, in turn, married Julianna née Markowska, the widow of Wojciech Milewski. They both were still alive in $1790^{90}$.

Andrzej Lubstowski, the elder son of Adam, the castellan of Kowal, and Zuzanna Trembińska (Trębińska), married around 1694 Ewa Dzierżek, the daughter of Adam and Katarzyna Borucka. He died in 1701. His wife, who after his death married Rafal Gomolinski, was no longer alive in 1724. Their only son was Adam. In 1721, he wrote a will and died childless the same year ${ }^{91}$. Maciej, the younger son of the castellan of Kowal, Adam, and Zuzanna Trembinska (Trębińska) married in 1695 Anna Grabska, Wczele coat of arms, the daughter of Piotr and Zofia Sierakowska, the niece of childless Stanisław, the castellan of Rogoźno, and of Kazimierz, the castellan of Srem. In 1717, he divided his father's landed estates with the above-mentioned nephew Adam. He died before 1721. The widow of him was certainly deceased in 1741. Maciej Lubstowski and Anna Grabska had three children: Andrzej, Zofia (Ewa Zofia) and Magdalena $^{92}$. In 1716, Zofia Lubstowska, the elder daughter of Maciej and Anna Grabska, married Andrzej Komierowski. In 1728, her husband appointed guardians for his children born from that marriage. All the children, however, died young. Andrzej Komierowski himself died around $1743^{93}$. Michał Kalkstein-Stoliński, Kos odm. coat of arms, was Ewa Zofia Lubstowska's second husband. He died in 1760 and she died childless around $1762^{94}$. Magdalena, the younger daughter of Maciej Lubstowski and Anna Grabska, became the wife of Andrzej Jarnowski, Topór coat of arms, in 1724.

${ }^{89}$ See BK PAN, TD, GiZ, Poznań, Inscriptions, $17^{\text {th }} / 18^{\text {th }}$ century, 6617 (No. 1270), 1743; GiZ, Gniezno, part 1, 12724 (No. 98), 1747; GiZ, Konin, 14971 (No. 80), 1770.

${ }^{90}$ See BK PAN, TD, GiZ, Gniezno, part 1, 13962 (No. 100), 1766; 15712 (No. 111), 1784; GiZ, Poznan, Inscriptions, $17^{\text {th }} / 18^{\text {th }}$ century, 17834 (No. 1367), 1790 .

${ }^{91}$ See BK PAN, TD, Monographies, Lubstowscy h. Leszczyc.

${ }^{92}$ See ibidem.

${ }^{93}$ See ibidem; and TD, ZTP, 6488 (No. 203), 1728; GiZ, Nakło, part 1, 6933 (No. 209), 1743.

${ }^{94}$ See BK PAN, TD, Monographies, Lubstowscy h. Leszczyc; GiZ, Nakło, part 1, 7326 (No. 11), 1760. 
They had sons Andrzej, Ignacy Bartłomiej (born 1733) and Wojciech Stanisław (born 1740) as well as daughter Elżbieta (born 1735). Ignacy died as a child. Elżbieta married Jan Ciechanowicz. She was mentioned as the widow of him in 1766. In 1773, Andrzej and Wojciech Jarnowski inherited goods and landed estates after the childless death of the nephew of their mother - Tomasz Lubstowski. Their future fate is unknown to me. Magdalena Jarnowska née Lubstowska died before $1759^{95}$.

In 1721, Andrzej Lubstowski, the only son of Maciej and Anna Grabska, married Małgorzata Elżbieta Kalkreyter, own coat of arms, the daughter of Adam and Florentyna Zofia Gorzeńska. He widowed in 1741. His second wife was Ewa Grochowicka, the daughter of Aleksander and Katarzyna née Dorpowska, the widow of Jakub Roman. Andrzej Lubstowski died in 1760. His second wife was no longer alive in 1772. She died childless. Andrzej's three children, Tomasz, Ludwik and Joanna Małgorzata, came from his first marriage ${ }^{96}$. The latter became the wife of Stefan Radoszewski, Oksza coat of arms (died 1780), the standard-bearer of Kowal. She was no longer alive in 1772. As she outlived all the children born from that marriage, her brother Tomasz inherited all her goods ${ }^{97}$. The younger son of Andrzej Lubstowski and Małgorzata Elżbieta Kalkreyter - Ludwik, was a Cistercian monk in the monastery in Lad. In 1747, he received 6000 zlotys from his father as his share in parental goods. Andrzej's elder son - Tomasz, born in 1724, died unmarried and childless on July 10, 1773. Sons of his aunt Magdalena - Wojciech and Andrzej Jarnowski, inherited his estates ${ }^{98}$. Tomasz was the last member of Lubstowski family who was descendant of Sigismund I the Old and Katarzyna Telniczanka.

Before 1686, Konstancja Szamowska, the only daughter of Franciszek and Zofia Lutomirska, married the Pomeranian standard-bearer, Michał Działyński, Ogończyk coat of arms (died on September 20, 1713), the son of Stanisław, the voivode of Malbork, and Marianna née Iwińska, Łodzia coat of arms, who after her death became the castellan of Brześć Kujawski. In 1691, she resigned from parental

${ }^{95}$ See BK PAN, TD, Parish registers, Catholic, 15017 (Barcin), 15019 (Barcin), 15026 (Barcin); GiZ, Kcynia, 3465 (No. 144), 1759; 3638, (No. 147), 1766; Gniezno, part 1, 14317 (No. 100), 1773.

${ }^{96}$ See BK PAN, TD, Monographies, Lubstowscy h. Leszczyc.

${ }^{97}$ See BK PAN, TD, GiZ, Kcynia, 3778 (No. 148), 1772.

${ }^{98}$ See BK PAN, TD, Monographies, Lubstowscy h. Leszczyc; and GiZ, Gniezno, part 1, 14317 (No. 100), 1773. 
goods. She died on April 8, 170 $1^{99}$. She had with Michał Działyński three daughters: Eleonora, Joanna and Ludwika. In 1708, Eleonora's hand was promised to Wojciech Zajaczek of Wrzaca, Świnka coat of arms, under a guarantee of 30,000 zlotys ${ }^{100}$. It is unknown, though, whether the deal was finalised because Zajaczek died shortly after. In that situation, on March 10,1710, Eleonora Działyńska married Jerzy Hieronim Latalski of Łabiszyn, Prawdzic coat of arms, the son of Władysław and Izabela Eufrozyna Mielęcka. Yet, already in 1721 she was mentioned as a widow. She died before 1738. The only son of Jerzy Hieronim Latalski and Eleonora née Działyńska was Władysław Latalski (their second son - Stanisław Jan, born in 1716, died in childhood). The date of Władysław Latalski's death is unknown. He was still alive in 1747 . He was mentioned as the deceased only as late as 1780 . He died childless as the last descendant of the Latalskis in Greater Poland ${ }^{101}$. On January 3, 1719, the second daughter of the castellan of Brześc Kujawski, Michał Działyński, and Konstancja née Szamowska - Joanna (born on May 30, 1700) married in Niechanowo Michał Boksa Radoszewski, Oksza coat of arms, the son of Stanisław and Anna Bojanowska. They had only one son - Jan. She died before $1739^{102}$. In 1753, Jan Boksa Radoszewski, the son of Michał and Joanna Działyńska, married Katarzyna Padniewska, Nowina coat of arms, the daughter of Antoni and Marcjanna Żółtowska. He was still alive in 1780 when his wife was mentioned as deceased. Jan Boksa Radoszewski died childless before $1793^{103}$. In 1722, the youngest daughter of Michał Działyński and Konstancja Szamowska - Ludwika, married Kazimierz Grabowiecki, Grzymała coat of arms, the son of Zygmunt and Dorota Skrzydlewska. They both were still alive in $1735^{104}$. I do not have any information about their future fate, though.

${ }^{99}$ See K. Piwarski, Działyński Michał († 1713), [in:] PSB, vol. VI, Kraków 1948, p. 92; AGAD, ŁGI, 285, sheets 232-232v; BK PAN, TD, Parish registers, Catholic, part 3, 17946 (Niechanowo).

100 See BK PAN, TD, GiZ, Gniezno, part 1, 10967 (No. 93), 1708.

${ }^{101}$ See BK PAN, TD, Monographies, Latalscy h. Prawdzic.

102 See BK PAN, TD, GiZ, Gniezno, part 1, 11376 (No. 94), 1719; 12643 (No. 97), 1739; Parish registers, Catholic, part 3, 17862 (Niechanowo); 17930 (Niechanowo). ${ }^{103}$ See BK PAN, TD, GiZ, Poznan, Inscriptions, $17^{\text {th }} / 18^{\text {th }}$ century, 12123 (No. 1309), 1753; Gniezno, part 1, 15125 (No. 107), 1780; 16576 (No. 117), 1793 (here it is clearly stated that Jan Boksa Radoszewski died childless).

${ }^{104}$ See BK PAN, TD, GiZ, Gniezno, part 1, 4966 (No. 1186), 1722; 12345 (No. 97), 1735 (here Ludwik Działyński, the starost of Powidz, is called Ludwika 
The younger son of Franciszek Szamowski and Zofia née Lutomirska - Jakub, married Katarzyna Gembicka, Nałęcz coat of arms, the daughter of Stefan, the castellan of Płock, and Anna Krasinska, Ślepowron coat of arms. They had only one daughter - Anna, who married Pawel Oborski, Roch II coat of arms, the standard-bearer of the Zawkrze county. He died after 1700 but before $1730^{105}$. Paweł Oborski and Anna Szamowska are said to have children. However, I have not found any source information to confirm it. The elder brother of Jakub Szamowski - Jan, was born around 1660. In 1687, he married Teresa Czermińska, Jelita coat of arms, the widow of Franciszek Piekarski. Jan's wife was the daughter of Jan Czermiński and Anna Myszkowska of Mirów, Jastrzębiec coat of arms. Jan died before 1700. He was mentioned as deceased in his father's will ${ }^{106}$. We do not know even the approximate date of his wife's death. Jan Szamowski and Teresa Czermińska had two sons: Antoni and Adam. Both brothers were mentioned as sons of Jan and Teresa in the act of December 1721 when they divided the property of Witaliszewice (Witaszyce) ${ }^{107}$. The younger brother - Adam Szamowski, married Ewa Jerzmanowska, Dołega coat of arms. They had son Felicjan Ignacy (born in 1725) as well as daughters Julianna Marianna (born 1732) and Anna. The first two died probably in childhood. Anna, in turn, married in 1754 the border bailiff of Sieradz, Franciszek Wardęski, Leliwa coat of $\operatorname{arms}^{108}$. It is unknown whether they had children.

The elder son of Jan Szamowski and Teresa Czermińska - Antoni, married Justyna Morawicka, Jelita coat of arms, the daughter of Krzysztof, the master of the pantry of Ciechanow, and Zofia Karbowska of Krzesimów, Sas coat of arms. Antoni's wife was born around 1692. In 1752, in the act of her death included in the books of the parish in Tum, it was noted that she lived 60 years. Antoni

Działyńska's brother. Yet, he was her stepbrother as he was the son of Michał and his second wife, Ludwika Niegolewska).

${ }^{105}$ See AGAD, Łęczyckie grodzkie, oblaty / The books of Łęczyca castle, records [hereinafter: $\mathrm{LGO}$ ] 4 , sheets $31 \mathrm{v}-34$.

106 See AGAD, ŁGI, 280, skeets $15 \mathrm{v}-17 \mathrm{v}$; ŁGR, 177, pp. 224-224v; M. Kobierecki, op. cit., p. 245 (here information about Teofila Grabska née Piekarska, the daughter of Teresa Czermińska and her first husband).

107 See AGAD, EGI, 329, sheets 324v-325.

${ }^{108}$ See Akta Stanu Cywilnego / The Civil Status Records [hereinafter: ASC] of the Góra św. Małgorzaty parish, 1725, 1732; of the Topola Królewska parish, 1754, Geneteka, baza Polskiego Towarzystwa Genealogicznego / Geneteka, database of the Polish Genealogical Society [hereinafter: Geneteka]. 
himself, born around 1690, probably died after $1747^{109}$. They had sons Felicjan and Ignacy as well as daughters Katarzyna and Anna. In 1740, the elder daughter of Antoni Szamowski and Justyna née Morawicka, Katarzyna, married Józef Grabowski. They had two daughters: Barbara Konstancja (born 1741) and Cecylia (1744$1746)^{110}$. The younger daughter of Antoni and Justyna Szamowska née Morawicka - Anna, married before 1746 Piotr Kossowski of Głogowa, Dołęga coat of arms, the Łęczyca master of the hunt's son. The couple had son Teodor Stanisław (born before 1746) and daughters - Franciszka (born ca. 1746) and Helena (born 1747). Teodor Kossowski probably died at a young age. His sister Franciszka married Wojciech Pieńkowski before 1766 with whom she had sons Nikodem (born 1766) and Ildefons Franciszek (born 1768). Franciszka Pieńkowska née Kossowska died in $1773^{111}$. I cannot say anything more about the future fate of Helena Kossowska.

The elder son of Antoni and Justyna née Morawicka was Felicjan Szamowski, born around 1719, who ended his career as the Orłow cup-bearer (1776-1787). He resigned from that post for the benefit of his son Ignacy. In 1746, Felicjan Szamowski married Eleonora Kwiatkowska, Gryf coat of arms (ca. 1728-1794), the daughter of the castellan of Inowłódz, Jan Jaksa Kwiatkowski, and Marianna née Dembińska. Felicjan and Eleonora Szamowska had 12 children: Magdalena (born ca. 1747), Marianna (born ca. 1748), Florian Augustyn (born 1750), Brygida Wiktoria (born 1754), Wincenty Kazimierz (born 1756), Katarzyna (born 1757), Ignacy (born 1758/59), Romuald Jan (born 1759/60), Onufry (born 1760), Mateusz Mikołaj (born 1765), Justyna Franciszka (born 1767) and Idzi Franciszek (ca. 1772-1774). Two daughters, Magdalena and Marianna, and four sons, Romuald Jan, Ignacy, Onufry and Mateusz Mikołaj, reached adulthood ${ }^{112}$. In 1774 , the eldest of the children of Felicjan and Eleonora Szamowska, Magdalena, married Antoni Dzierzbicki,

${ }^{109}$ See AGAD, ŁGI, 343, sheets 54v-55v; ASC of the Tum parish, 1752, Geneteka; M. Kobierecki, op. cit., p. 245.

${ }^{110}$ See ASC of the Łęczyca parish, 1741; of the Topola Królewska parish, 1740, 1746, Geneteka.

${ }^{111}$ See ASC of the Piatek parish, 1768, 1773; of the Kutno-Łakoszyn parish, 1766, Geneteka.

${ }^{112}$ See H. Żerek-Kleszcz, Szamowski Ignacy, [in:] PSB, vol. XLVI, p. 589; ASC of the Rdutow parish, 1748, 1750, 1768; of the Tum parish 1754, 1756, 1757, 1759, $1760,1765,1767,1773,1774,1794$ (here it is stated that Eleonora Szamowska née Kwiatkowska was 66 years old when she died), 1803 (here information that Felicjan Szamowski lived 84 years), Geneteka. 
Topór coat of arms (died ca. 1780), the cup-bearer of Inowłódz, later Orłow master of the pantry. They had son Wawrzyniec and daughter Urszula. In 1790, that is 10 years after the death of her first husband, Magdalena Szamowska married Konstanty Pilchowski ${ }^{113}$. In 1804, the second daughter of Felicjan Szamowski and Eleonora née Kwiatkowska, Marianna, married Andrzej Kozerski. She was more over 50 years old at the time. She died in $1808^{114}$.

The eldest son of Felicjan and Eleonora Szamowska who reached adulthood, Ignacy, was the Orłów cup-bearer. He was an opponent of the Constitution on May 3 and one of the organisers of the Targowica confederation in the Łeczyca voivodship. In 1809, he became a member of parliament, and in 1811 - the deputy from the district of Łęczyca and Orłów. He was a colonel of the Polish Army at that time, too. He died on October 24, 1827. In 1802, in Warsaw, he married Rozalia née Zawadzka (died on March 23, 1850), the daughter of Andrzej, the police director in Łowicz, and Magdalena née Barszcz. The only son of Ignacy and Rozalia Zawadzka was Eugeniusz Kajetan Szamowski (died on February 27, 1870), who was born in the beginning of August 1802 $2^{115}$. Another son of Felicjan Szamowski and Eleonora née Kwiatkowska - Romuald Jan, died as a bachelor in 1795 at the age of $35^{116}$. Next of the Szamowski brothers - Onufry, was the standard-bearer of the national cavalry ${ }^{117}$. Nothing more could be said about him. The fourth son of Felicjan and Eleonora Szamowska - Mateusz Mikołaj, was the royal chamberlain. Around 1790, he married Marianna née Poleska, Krzywda coat of arms (born on December 12, 1773), the daughter of Ludwik and Wiktoria Rozdrażewska, Doliwa coat of arms. He died on June 1, 1835, leaving a widowed wife and three daughters: Magdalena, Teresa and Felicjanna ${ }^{118}$.

Ignacy Szamowski was the younger son of Antoni and Justyna Morawicka. He was born at the turn of 1736 and 1737 (he was baptised on February 23, 1737). On August 5, 1756, together with

${ }^{113}$ See AGAD, ŁGI, 383, sheets 94-94v; H. Żerek-Kleszcz, op. cit., p. 589; ASC of the Tum parish, 1790, Geneteka.

${ }^{114}$ See ASC of the Łeczyca parish, 1804, 1808, Geneteka.

${ }^{115}$ See H. Żerek-Kleszcz, op. cit., p. 589; ASC of the Łowicz Kolegiata parish, 1802; of the Tum parish, 1802, Geneteka.

${ }^{116}$ See ASC of the Tum parish, 1795, Geneteka.

117 See H. Żerek-Kleszcz, op. cit., p. 589.

${ }^{118}$ See H. Żerek-Kleszcz, op. cit., p. 589; BK PAN, TD, Parish registers, Catholic, part 3, 19560 (Słupy); ASC of the Rdutów parish, 1835, Geneteka. 
his brother Felicjan, he divided goods and landed estates of their parents. He married Wiktoria Stokowska of Romiszewice, Jelita coat of arms, the daughter of Adam (ca. 1703-1783), the standard-bearer of Brzeziny, and Marianna Magdalena Rojek, Rawicz coat of arms (1711-1790). In the years 1780-1792, Ignacy Szamowski was the treasurer of Inowłódz. He resigned from the post on the benefit of his only son. He died in Rycerzew on October 4, $1803^{119}$. Ignacy Szamowski and Wiktoria Stokowska had four children: Mechtylda Rozalia (born 1763), the twins Estera Elżbieta and Małgorzata Magdalena (born in 1765) ${ }^{120}$ and Antoni. The twins died in childhood. Around 1790, Mechtylda Rozalia Szamowska (she used only the second name), the daughter of Ignacy and Wiktoria née Stokowska, married Tomasz Byszewski, Jastrzębiec coat of arms (1759-1840), the land regent of Łęczyca and deputy to the Great Diet. They had three daughters: Marta (born 1791), Zofia Joanna (born 1793) and Franciszka Tekla (only she outlived the parents) ${ }^{121}$. In 1792, that is after his father's resignation, Antoni Szamowski, the only son of Ignacy and Wiktoria Stokowska, became the treasurer of Inowłódz. Around 1791, he married Tekla Ludwika Poleska, Krzywda coat of arms (born 1772), the daughter of Ludwik and Wiktoria née Rozdrażewska, Doliwa coat of arms, who was the sister of Marianna, the wife of his first cousin, Mateusz Szamowski. Antoni and Tekla Szamowska had 12 children: Jakub Pantaleon (born 1792), Wit Modest (born 1794), Dionizy Felicjan (born 1795), Katarzyna (born 1797), Karolina Luiza (1802-1804), Grzegorz Józef (born 1804) and Elżbieta, Dominik, Alojzy, Napoleon as well as Ludwik August. Andrzej was probably their son, too. He died in Tymienica (a village belonging to Antoni at that time) in $1794^{122}$. Antoni Szamowski died before December 1, 1813, and his wife died in Rycerzew on July 7, 1822. After Antoni's death, the Guardian Council was established that was to take care of the material

${ }^{119}$ See H. Żerek-Kleszcz, Stokowski Jan Sariusz, [in:] PSB, vol. XLIV, Warszawa-Kraków 2006-2007, p. 47; Urzędnicy województw..., p. 47; AGAD, ŁGO, 108, sheet 269; 145, sheets 97-100v; ASC of the Tum parish, 1737; of the Rdutów parish, 1803, Geneteka.

${ }^{120}$ See ASC of the Rdutów parish, 1763, 1765, Geneteka.

${ }^{121}$ See AGAD, ŁGI, 396, sheet 245; ASC of the Rdutów parish, 1791, 1793, 1840, Geneteka.

${ }^{122}$ See Urzędnicy województw..., p. 48; APŁ, Magistrate's court of the Łęczyca county [hereinafter: SPPŁ], 5, p. 2 and the following, pp. 89-153; BK PAN, TD, Parish registers, Catholic, part 3, 19559 (Słupy); ASC of the Góra św. Małgorzaty parish, 1794, 1795; of the Rdutów parish, 1797, 1804. 
interests of his underage children. We know from the documents that seven children outlived the father - daughters Elżbieta and Katarzyna and sons Jakub, Dominik, Alojzy, Napoleon as well as Ludwik August. In the death certificate of Tekla Szamowska née Poleska, it was mentioned that she had orphaned two daughters and five sons ${ }^{123}$.

We should end our deliberations at this point because Antoni's children, like children of his first cousins' from the Felicjan's line, were living in the $19^{\text {th }}$ century which goes beyond the chronological frame of the study. It is worth to conclude that all the descendants of Sigismund I the Old and Katarzyna Telniczanka, who were born at the turn of the $18^{\text {th }}$ and $19^{\text {th }}$ century, derived from the granddaughter of the king - Anna Kreza née Szafraniec, her son Jan Kreza, the granddaughter Zofia Lutomirska née Kreza and the great-granddaughter Zofia née Lutomirska $1^{\text {st }}$ married Stanisław Trembiński (Trębiński), $2^{\text {nd }}$ married Franciszek Szamowski. Among 114 identified descendants of the penultimate Jagiellon on the Polish throne, there were 58 men and 56 women born between the beginning of the $16^{\text {th }}$ and the turn of the $18^{\text {th }}$ and $19^{\text {th }}$ century (the calculation excluded children of Sigismund I the Old and Katarzyna Telniczanka). It should be underlined, however, that at least 23 persons from that group (13 boys and 10 girls) died as children or young people. It is also worth emphasizing that until the end of the first quarter of the $17^{\text {th }}$ century, all the descendants of Sigismund I the Old's elder illegitimate daughter were Calvinists. We should also add that among the king's descendants known to me, representatives of the wealthy and middleclass nobility dominated. Yet, there is no magnate at this group. None of the royal descendants never sat in the senate (unless there will be found an evidence that the Czechów castellan, Dobiesław Ciekliński, was the grandson of Florian and Anna Kreza), and only a few were land officers. Only two young ladies from the population in question became wives of future senators (Zuzanna Trembińska (Trębińska) married to Adam Lubstowski, Konstancja Szamowska married to Michał Działyński). Still, their husbands became the senators after their wives' deaths. Only two men married the senator's daughters - Jakub Szamowski married Katarzyna Gembicka and Felicjan Szamowski married Eleonora Kwiatkowska. Only a few

${ }^{123}$ See APŁ, SPPŁ, 5, passim; ASC of the Rdutów parish, 1822, Geneteka. 
descendants of Sigismund I were of the so-called grand-senators families (three children of Baltazar Lutomirski, three daughters of Michał Działyński and one representative of the Latalski family). It should be noted, however, that those were the families (perhaps excluding the Działyńskis) that lost their fortunes and political influence in the discussed period (the Lutomirskis in the $17^{\text {th }}$ century and the Latalskis in the $18^{\text {th }}$ century). It is also important to note that being a descendant of the illegitimate daughter of the penultimate Jagiellon on the Polish throne did not favour nor helped the making of individual careers in the old Polish times. It may be assumed that in the following generations the fact that one of the ancestors of Zofia née Lutomirska $1^{\text {st }}$ married Stanisław Trembiński (Trębiński), $2^{\text {nd }}$ married Franciszek Szamowski was Sigismund I, King of Poland and Grand Duke of Lithuania, was blurred. Finally, let us add that the presented list of the Polish descendants of Sigismund I the Old and Katarzyna Telniczanka is incomplete. Thus, next researchers may fill that research gap. It is also important to underline that among the contemporary Poles there are undoubtedly the descendants of the elder of Sigismund I the Old's illegitimate daughters. It does not seem, however, that this is a particularly large population. There are certainly much fewer descendants of the king and Katarzyna Telniczanka than of the Duke of Racibórz, Wenceslaus II.

\section{Bibliography}

\section{Archival sources}

Archiwum Główne Akt Dawnych w Warszawie [AGAD]

(The Central Archives of Historical Records in Warsaw)

Metryka Koronna [MK] / The Crown Metrica 78, 111, 112, 133, 134, 135, 137, $138,180$.

Łęczyckie grodzkie, inskrypcje [ŁGI] / The books of Łęczyca castle, inscriptions 169, 175, 215, 220, 280, 285, 329, 343, 383, 396.

Łęczyckie grodzkie, oblaty [ŁGO] / The books of Łęczyca castle, records 4, 108. Łęczyckie grodzkie, relacje / The books of Łęczyca castle, accounts 177 .

Sieradzkie grodzkie, inskrypcje [SGI] / The books of Sieradz castle, inscriptions 103, 137, 139, 149.

Sieradzkie grodzkie, relacyjne / The books of Sieradz castle, accounts 28a. 
Archiwum Narodowe w Krakowie [ANK]

(The National Archives in Cracow)

Castriensia Cracoviensia Inscriptiones [CCI] No. 89, 91, 148, 187, 224, 278.

Archiwum Państwowe w Łodzi [APŁ]

(The State Archive in Łódz)

Archiwum Leopoldow $z$ Rzepiszewa [ALzRz] / The Archives of Leopolds of Rzepiszew No. 13, 30, 54.

Sąd pokoju powiatu łęczyckiego [SPPŁ] / The magistrate's court of the Łęczyca county 5 .

Biblioteka Kórnicka PAN [BK PAN]

(The Kórnik Library of the PAS), Teki Dworzaczka.

\section{Printed sources}

Akta sejmikowe województwa krakowskiego, vol. I (1572-1620), ed. S. Kutrzeba, Kraków 1932.

Die Metrikel der Universität Heidelberg von 1386 bis 1662, hrsg. von G. Toepke, Bd. II, Heidelberg 1886.

Paprocki B., Herby rycerstwa polskiego, ed. K.J. Turowski, Kraków 1858.

Starowolski S., Monumenta Sarmatarum, Cracoviae 1655.

Trepka Nekanda W., Liber generationis plebeanorum 'Liber chamorum', eds W. Dworzaczek, J. Bartyś, Z. Kuchowicz, part 1 (Wstępy wydawców i tekst), Wrocław-Warszawa-Kraków 1963.

Volumina legum, ed. J. Ohryzko, vol. II, Petersburg 1859.

Źródła i materiały do dziejów szlachty województwa sandomierskiego $w$ XVI-XVIII wieku, vol. I (Rejestry pospolitego ruszenia szlachty sandomierskiej z XVII wieku), elaboration J. Pielas, Kielce 2009.

\section{STUdies}

Biblioteka Kórnicka PAN [BK PAN], Teki Dworzaczka [TD], Monografie / The Kórnik Library of the PAS, Teki Dworzaczka, Monographs.

Biedrzycka A., Szafraniec Hieronim (Jarosz) z Pieskowej Skały, [in:] Polski słownik biograficzny, vol. XLVI, Warszawa-Kraków 2009-2010, pp. 436-439.

Boniecki A., Herbarz polski, vol. III, Warszawa 1900; vol. XII, Warszawa 1908.

Borkowska U., Dynastia Jagiellonów w Polsce, Warszawa 2011.

Burmeister K.H., Graf Georg III. von Montfort-Bregenz-Pfannberg (ca. 1475/801544). Eine biographische Skizze, 'Monfort. Vierteljährensschrift für Geschichte, Heimat - und Volkskunde (Gegenwart) Vorarlbergs' 2009, Bd. LXI, pp. 7-27.

Burmeister K.H., Montfort, von (Grafen von Montfort), [in:] Neue Deutsche Biographie, Bd. XVIII, Berlin 1997, pp. 51-54.

Chłapowski K., Realizacja reform egzekucji dóbr 1563-1665. Sprawa zastawów królewszczyzn małopolskich, Warszawa 1984. 
Czapliński W., Ciekliński Dobiesław, [in:] Polski słownik biograficzny, vol. IV, Kraków 1938, p. 42.

Estreicher K., Bibliografia polska, vol. XIV, Kraków 1896.

Kaniewska I., Szafraniec Stanisław z Pieskowej Skały, [in:] Polski słownik biograficzny, vol. XLVI, Warszawa-Kraków 2009-2010, pp. 471-479.

Kempa T., Dzieje rodu Ostrogskich, Toruń 2003.

Kobierecki M., Walewscy herbu Kolumna w XVII-XVIII wieku. Genealogia. Majętności. Działalność publiczna, Łódź 2008.

Kowalska H., Grzegorz z Żarnowca, [in:] Polski słownik biograficzny, vol. IX, Wrocław-Warszawa-Kraków 1960-1961, pp. 91-93.

Kurdybacha Ł., Fogelweder Stanisław, [in:] Polski słownik biograficzny, vol. VII, Kraków 1948-1958, pp. 44-46.

Kurtyka J., Latyfundium tęczyńskie. Dobra i właściciele (XIV-XVII wiek), Kraków 1999.

Łukaszewicz J., Dzieje kościołów wyznania helweckiego w Litwie, vol. I, Poznań 1842.

Łukaszewicz J., O kościołach braci czeskich w dawnej Wielkopolsce, Poznań 1835.

Michałek A., Ciekliński Stanisław, [in:] Polski słownik biograficzny, vol. IV, Kraków 1938, p. 45.

Niesiecki K., Herbarz polski, ed. J.N. Bobrowicz, vol. III, Lipsk 1839; vol. V, Lipsk 1840; vol. VIII, Lipsk 1841.

Pielas J., Oleśniccy herbu Dębno w XVI-XVII wieku. Studium z dziejów zamożnej szlachty doby nowożytnej, Kielce 2007.

Pielas J., Urzędnicy grodzcy nowokorczyńscy i ich kariery w XVII wieku, [in:] Dzieje biurokracji, vol. IV, part 1-2, eds A. Górak, K. Latawiec, D. Magier, LublinSiedlce 2011, pp. 137-152.

Piwarski K., Działyński Michał († 1713), [in:] Polski słownik biograficzny, vol. VI, Kraków 1948, p. 92.

Prinke R.T., Sikorski A., Polscy potomkowie Piastów i innych dynastii panujacych, Poznań 1997.

Quirini-Popławska D., Kreza Mikołaj, [in:] Polski słownik biograficzny, vol. XV, Wrocław-Warszawa-Kraków 1970, p. 295.

Schmitt H., Kilka uwag w sprawie rokoszu Zebrzydowskiego, 'Roczniki Towarzystwa Przyjaciół Nauk Poznańskiego', vol. III, Poznań 1865, pp. 1-86.

Swieżawski A., Jan (Janusz) z Książat Litewskich, [in:] Polski słownik biograficzny, vol. X, Wrocław-Warszawa-Kraków 1962-1964, pp. 439-441.

Swieżawski A., Kościelecka (z Kościelca) Katarzyna, [in:] Polski słownik biograficzny, vol. XIV, Wrocław-Warszawa-Kraków 1968-1969, pp. 397-398.

Swieżawski A., Kościelecki (z Kościelca) Andrzej, [in:] Polski słownik biograficzny, vol. XIV, Wrocław-Warszawa-Kraków 1968-1969, pp. 398-400.

Szczotka S., Chełmski Remigian, [in:] Polski słownik biograficzny, vol. III, Kraków 1937, p. 286. 
Szybkowski S., Zwiazki rodzinne Danaborskich z elita urzędnicza Kujaw i ziemi dobrzyńskiej, 'Roczniki Historyczne' 2000, LXIV, pp. 157-168.

Tazbir J., Bluźniercy, którzy uszli karze, 'Nauka' 2011, No. 1, pp. 7-16.

Urban W., Umiejętność pisania w Małopolsce w drugiej połowie XVI wieku, 'Przeglad Historyczny' 1977, vol. LXVIII, issue 2, pp. 231-257.

Uruski S., Kosiński A.A., Włodarski A., Rodzina. Herbarz szlachty polskiej, vol. II, Warszawa 1905.

Urzędnicy kujawscy i dobrzyńscy XVI-XVIII wieku. Spisy, elaboration K. Mikulski, W. Stanek, Z. Górski, R. Kabaciński, ed. A. Gąsiorowski, Kórnik 1990.

Urzędnicy województw łęczyckiego i sieradzkiego w XVI-XVIII wieku. Spisy, elaboration E. Opaliński, H. Żerek-Kleszcz, ed. A. Gąsiorowski, Kórnik 1993.

Vanotti J.N., Geschichte der Grafen von Montfort und von Werdenberg, Belle-Vue, bei Constanz 1845.

Wdowiszewski Z., Genealogia Jagiellonów i Domu Wazów w Polsce, Kraków 2005.

Wierzbicki L.A., Szamowski Franciszek, [in:] Polski słownik biograficzny, vol. XLVI, Warszawa-Kraków 2009-2010, pp. 588-589.

Wijaczka J., Reformacja $w$ miastach prywatnych $w$ Koronie $w$ XVI wieku, 'Roczniki Dziejów Społecznych i Gospodarczych' 2016, vol. LXXVII, pp. 379-406.

Żelewski R., Górkowa Elżbieta (Halszka z Ostroga), [in:] Polski słownik biograficzny, vol. VIII, Wrocław-Warszawa-Kraków 1959-1960, pp. 424-426.

Żelewski R., Katarzyna (ok. 1503-1548), żona Jerzego II hr. Montfortu, [in:] Polski słownik biograficzny, vol. XII, Wrocław-Warszawa-Kraków 1966-1967, p. 222.

Żelewski R., Łaska 1. v. Ostrogska z Kościeleckich Beata, [in:] Polski słownik biograficzny, vol. XVIII, Wrocław-Warszawa-Kraków 1973, pp. 222-224.

Żelewski R., Łaski Olbracht, [in:] Polski słownik biograficzny, vol. XVIII, WrocławWarszawa-Kraków 1973, pp. 246-250.

Żelewski R., Ostrogski Ilia (Eliasz), [in:] Polski słownik biograficzny, vol. XXIV, Wrocław 1979, pp. 480-481.

Żerek-Kleszcz H., Stokowski Jan Sariusz, [in:] Polski słownik biograficzny, vol. XLIV, Warszawa-Kraków 2006-2007, pp. 47-50.

Żerek-Kleszcz H., Szamowski Ignacy, [in:] Polski słownik biograficzny, vol. XLVI, Warszawa-Kraków 2009-2010, pp. 589-590.

Żołądź D., Studenci polscy z Korony i Litwy na uniwersytecie $w$ Heidelbergu w okresie reformacji, 'Rozprawy z Dziejów Oświaty’ 1994, vol. XXXVI, pp. 3-17.

\section{INTERNET SOURCES}

Geneteka, database of the Polish Genealogical Society [Geneteka]. 
ZBIGNIEW ANUSIK

\title{
Królewska krew. Polscy potomkowie Zygmunta Starego i Katarzyny Telniczanki w czasach staropolskich
}

\begin{abstract}
$\mathrm{P}$ rzedmiotem badań podjętych przez Autora jest zbiorowość polskich potomków Reginy, starszej z dwóch córek króla Zygmunta I Starego i jego długoletniej kochanki - Katarzyny Telniczanki. Do tej pory przyjmowano, że ostatnimi potomkami króla byli żyjący w pierwszej połowie XVII w. jego praprawnukowie - Władysław i Krystyna z Białaczowa Straszowie. Dzięki odnalezionym przez Autora dokumentom udało się jednak ustalić, że matka wspomnianych Władysława i Krystyny Straszów - Urszula z Krezów Straszowa miała siostrę - Zofię, która poślubiła Baltazara Lutomirskiego. Od jej córki, Zofii $z$ Lutomirskich $1^{\circ} \mathrm{v}$. Trembińskiej (Trębińskiej) $2^{\circ}$ v. Szamowskiej pochodzą wszyscy, tak historyczni, jak i żyjący do dziś potomkowie Zygmunta Starego i Katarzyny Telniczanki. $\mathrm{W}$ artykule przedstawiono listę wszystkich descendentów króla żyjących od początku XVI do przełomu XVIII i XIX w. W sumie było to 113 osób (57 mężczyzn i 56 kobiet). Zwraca uwagę to, że do końca pierwszej ćwierci XVII w. potomkowie Zygmunta I i Katarzyny Telniczanki wyznawali kalwinizm. W całym badanym okresie byli to niemal wyłącznie przedstawiciele zamożnej i średniej szlachty. Nie było wśród nich senatorów, a tylko nieliczni pełnili urzędy ziemskie. Autor zwraca też uwage na to, że sporządzona przez niego lista potomków przedostatniego Jagiellona na polskim tronie nie jest bynajmniej zamknięta. W kilku przypadkach nie udało się bowiem znaleźć źródłowego potwierdzenia na to, czy wspomniana w artykule para małżeńska miała dzieci. Wiele razy Autor musiał zatem poprzestać na stwierdzeniu, że dalsze losy jakiejś osoby sa mu nieznane. Otwiera to przed następnymi badaczami szansę na znaczące uzupełnienie jego ustaleń.
\end{abstract}

Słowa kluczowe: Zygmunt I Stary, Katarzyna Telniczanka, genealogia, potomkowie nieślubnych córek Zygmunta Starego w XVI-XVIII w. 